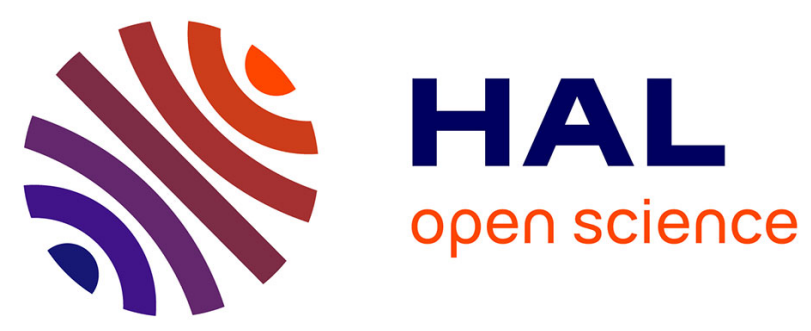

\title{
The untold story of pyrocumulonimbus
}

\author{
Michael Fromm, Daniel T. Lindsey, René Servranckx, Glenn Yue, Thomas \\ Trickl, Robert Sica, Paul Doucet, Sophie Godin-Beekmann
}

\section{To cite this version:}

Michael Fromm, Daniel T. Lindsey, René Servranckx, Glenn Yue, Thomas Trickl, et al.. The untold story of pyrocumulonimbus. Bulletin of the American Meteorological Society, 2010, 91 (9), pp.11931209. 10.1175/2010BAMS3004.1. hal-00475856

\section{HAL Id: hal-00475856 https://hal.science/hal-00475856}

Submitted on 16 Dec 2020

HAL is a multi-disciplinary open access archive for the deposit and dissemination of scientific research documents, whether they are published or not. The documents may come from teaching and research institutions in France or abroad, or from public or private research centers.
L'archive ouverte pluridisciplinaire HAL, est destinée au dépôt et à la diffusion de documents scientifiques de niveau recherche, publiés ou non, émanant des établissements d'enseignement et de recherche français ou étrangers, des laboratoires publics ou privés. 


\title{
THE UNTOLD STORY OF PYROCUMULONIMBUS
}

\author{
by Michael Fromm, Daniel T. Lindsey, René Servranckx, Glenn Yue, Thomas Trickl, \\ Robert Sica, Paul Doucet, and Sophie Godin-Beekmann
}

\section{When fires initiate or intensify towering thunderstorms, they can inject aerosols into the lower stratosphere that were once thought to originate only from volcanic plumes.}

W ildfire is becoming a focus of increasing attention. It is now realized that changes in the occurrence frequency and intensity of wildfires have significant consequences for a variety of important problems, including atmospheric change and safety in the urban-wildland interface. One important but poorly understood aspect of wildfire behavior-pyrocumulonimbus firestorm dynamics and atmospheric impact-has a curious history of theory and observation. The "pyroCb" is a fire-started

AFFILIATIONS: FROMM-Naval Research Laboratory, Washington, D.C.; LINDSEY - NOAA, Fort Collins, Colorado; Servranckx-Canadian Meteorological Centre, Dorval, Québec, Canada; Yue-NASA Langley Research Center, Hampton, Virginia; TRICKL-Karlsruher Institut für Technologie, IMK-IFU, GarmischPartenkirchen, Germany; SICA AND DouCET-Department of Physics and Astronomy, The University of Western Ontario, London, Ontario, Canada; Godin-BeEkMANN-Laboratoire Atmosphère, Milieux, Observations Spatiale, UPMC-CNRS, Paris, France CORRESPONDING AUTHOR: Micahel Fromm, Naval Research Laboratory, US Naval Research Lab 4555 Overlook Ave., SW Washington, DC 20375

E-mail: mike.fromm@nrl.navy.mil

The abstract for this article can be found in this issue, following the table of contents.

DOI:10.1175/2010BAMS3004.I

In final form 31 March 2010

(C)2010 American Meteorological Society or fire-augmented thunderstorm that in its most extreme manifestation injects huge abundances of smoke and other biomass-burning emissions into the lower stratosphere. The observed hemispheric spread of smoke and other biomass-burning emissions could have important climate consequences. PyroCbs have been spawned naturally and through anthropogenesis, and they are hypothesized to be part of the theoretical "nuclear winter" scenario. However, direct attribution of the stratospheric aerosols to pyroCbs only occurred in the last decade. Such an extreme injection by thunderstorms was previously judged to be unlikely because the extratopical tropopause is considered to be a strong barrier to convection.

Two recurring themes have developed as pyroCb research unfolds. First, some "mystery layer" eventspuzzling stratospheric aerosol-layer observationsand other layers reported as volcanic aerosol can now be explained in terms of pyroconvection. Second, pyroCb events occur surprisingly frequently, and they are likely a relevant aspect of several historic wildfires. Here we show that pyroCbs offer a plausible alternate explanation for phenomena that were previously assumed to involve volcanic aerosols in 1989-91. In addition, we survey the Canada/U.S. fire season of 2002 and identify 17 pyroCbs, some of which are associated with newsworthy fires, such as the Hayman, Rodeo/ Chediski, and Biscuit Fires. Some of these pyroCbs injected smoke into the lowermost stratosphere. 
Wildfire, and its relation to weather, climate, and society, is a topic of increasing interest and attention. For instance, the Hayman Fire (Colorado) exploded from a human-caused ignition into a firestorm that burned 24,000 ha and advanced $31 \mathrm{~km}$ in its first 24 h (Graham 2003). Australia's capital, Canberra, was overwhelmed by a lightning-started bushfire in January 2003 that brought death and wholesale destruction of property (Webb et al. 2004). San Diego, California, was under siege in October 2003 by the human-caused Cedar Fire, which consumed an area unprecedented in California history (U.S. Forest Service 2004). In 1988, 558,000 ha of the Greater Yellowstone Area were torched by wildfires that were historic in their intensity and community impact (Alexander 2009). Fires in Greece in 2007 and 2009 were major news events; in 2009, the government faced strong criticism for the recurrence of death and destruction after just $2 \mathrm{yr}$.

Global and regional warming trends have been identified and associated with exacerbated wildfire occurrence and impact (Stocks et al. 1998; Westerling et al. 2006). Attention to this topic has been heightened with growing concern regarding anthropogenic climate forcing and the apparent increase of fire in the wildland-urban interface. Superimposed on this important topic is a relatively new discovery. In 1998 a remarkable manifestation of extreme wildfire impact was identified: there was smoke in the stratosphere that was hemispheric in scope, spanning into the stratospheric "overworld" (Fromm et al. 2000). The cause is now known to be a particularly energetic form of blowup: pyrocumulonimbus (pyroCb; see McGraw-Hill Yearbook of Science and Technology, 1st ed., s.v. "pyrocumulonimbus"). Pyrocumulus convection, which is readily apparent to the observer of fire, has been well known for decades. Large-scale firestorms such as those created in the World War II bombing of Hamburg, Germany (Ebert 1963), were anecdotally known to inject smoke palls into the upper troposphere. Investigation of the hypothesized nuclear winter (Turco et al. 1983) involved attempts to simulate deep pyroconvection in computer models (Gostintsev et al. 1991) and discern vertical transport from actual blowups (Pyne and Omi 1986; Westphal and Toon 1991). However, observations of smoke deep in the lower stratosphere (LS) and its direct attribution to pyroCb (e.g., Jost et al. 2004) have only been achieved since about 2000. A host of studies of "regular" cumulonimbus convection (associated with general meteorological forcing) have given observations of the efficiency with which such storms redistribute boundary layer material to the upper troposphere and lower stratosphere (UTLS; see Poulida et al. 1996; Thompson et al. 1996; Randriambelo et al. 1999). Other studies of convective cloud tops, using observations and models, strongly suggest irreversible transport of water-ice and vapor into the lowermost stratosphere (e.g., Wang 2007). However, within that context, the pyroCb is now being revealed to be a unique form of convection in terms of cloud microphysics (e.g., Andreae at al. 2004; Rosenfeld et al. 2007) and lifetime (Lindsey and Fromm 2008), in addition to its power to pollute the stratosphere (Fromm et al. 2005, 2008a,b).

Reports of confirmed pyroCbs and stratospheric impact are increasing in the scientific literature, but the entire body of published cases accounts for fewer than 10 events (Jost et al. 2004; Livesey et al. 2004; Fromm et al. 2006; Damoah et al. 2006; Lindsey and Fromm 2008; Cammas et al. 2009). However, since the advent of the "satellite era" ${ }^{2}$ in 1979, several stratospheric mystery-layer events have been reported (e.g., Bluth et al. 1997; Clancy 1986; Evans and Kerr 1983). Moreover, in the literature one can find other cases wherein stratospheric aerosol layers are attributed to volcanic eruptions when no clear evidence of such an event exists (Yue et al. 1994). Even the aftermath of a definitive stratospheric volcanic injection such as the 1991 eruption of Mount Pinatubo has involved aerosol patterns that investigators have had difficulty reconciling with expectations (e.g., Thomason 1992). Finally, the literature contains some reports of thin LS cloud layers inferred to be water-ice residue from overshooting convection (e.g., Neilsen et al. 2007) that have been challenged in terms of pyroCb-caused smoke (available online at www. atmos-chem-phys-discuss.net/6/9003/2006/acpd-69003-2006-discussion.html). Might the pyroCb, still in its infancy of understanding, be a contributor to some of these phenomena? Now that the pyroCb has been characterized, does the evidence of such mysterious or challenging stratospheric observations allow us to reinterpret earlier assessments? More generally,

\footnotetext{
1 "Overworld," a term coined by J. Holton, is the range of stratospheric altitudes roughly greater than the 380-K potential temperature surface. This threshold generally defines the absolute top of the tropopause region anywhere on the globe.

${ }^{2}$ The "satellite era" for our purposes is defined as beginning in 1979, when polar-orbiting weather satellites went into service with imaging and Earth radiation budget instruments, along with other instruments such as the National Aeronautics and Space Administration's (NASA's) Total Ozone Mapping Spectrometer (TOMS), and a host of solar occultation devices.
} 
can satellite-era data be exploited to go beyond case studies toward a pyroCb climatology? If so, a broad new understanding of the scale of wildfire activity, its relation to weather, and interaction with climate change is within reach.

Here we identify three individual cases in which stratospheric pyroCb impact has been missed or misidentified. We employ nadir-viewing polar orbiter and geosynchronous satellite image data, satellitebased profile data, and ground-based lidar data in this pursuit. Using these resources we present evidence for a reinterpretation of selected stratospheric mysterylayer or volcanic aerosol reports in the literature. In addition, we present an in-depth characterization of the seasonal occurrence of wildfire, pyroCb, and the resulting smoke plumes in North America.

PYROCB VERSUS VOLCANO. The canonical model of LS aerosol is that the ultimate source/pathway for its material is the troposphere, and that material enters the LS by two primary irreversible mechanisms: slow cross-tropopause ascent in the tropics and rapid injection by volcanic eruptions (Thomason and Peter 2006). While there is still uncertainty and active research regarding these and other mechanisms (e.g., Khaykin et al. 2009; Dessler et al. 2007; Wang 2007), models of the lower and middle atmosphere do not take into account any other routine process for troposphere-to-stratosphere transport.

Aerosols, being a basic atmospheric constituent, are a fundamental tracer of polluting processes that affect both the troposphere and stratosphere. Regarding the stratosphere, observational and model analyses of aerosols are a basic means for understanding dynamics (e.g., Trepte and Hitchman 1992), patterns, and trends (e.g., Deshler 2008). Since the discovery by Junge et al. (1961) of a stratospheric "background" of liquid sulfate particles, temporal and spatial changes to this "layer" have been well documented with the aid of space- and groundbased profiling instruments (e.g., Jäger 2005; Deshler et al. 2006; Hofmann 1990; Hofmann et al. 2009; Thomason and Peter 2006). One seasonal/regional stratospheric aerosol peculiarity that has also been extensively studied is the polar stratospheric cloud (PSC). These form generally inside the winter polar vortex and are caused by adiabatic and diabatic cooling of air masses leading to condensation and/or freezing (e.g., McCormick et al. 1981; Browell et al. 1990; Toon et al. 1990).

Decadal studies of stratospheric aerosol loading generally conform to the above mentioned canonical model (Deshler 2008). However, one study reports departures of measured stratospheric aerosol burdens from modeled volcanic decay, with findings that indicate "several limitations in our knowledge of the volcano-atmosphere reactions..." (Bluth et al. 1997). Fromm et al. (2008a) reported that a single pyroCb injection in 2001 deposited into the LS an aerosol mass representing $>5 \%$ of Northern Hemispheric LS background levels. Hence, it seems our understanding of the LS aerosol processes is far from complete.

THREE MYSTERY CLOUD YEARS. In the northern summers from 1989 through 1991, puzzling LS aerosol features were observed from ground and space. Sassen and Horel (1990, hereafter SH90) reported on perplexing lidar signals-depolarizing LS layers-at Salt Lake City, Utah, in August 1989. They concluded that the aerosols were volcanic in origin even though no confirmed LS volcanic injection occurred. In the summer of 1990 there was an impressive and sudden increase in LS aerosol loading in the northern middle and high latitudes, according to Yue et al. (1994). They analyzed an entire season of Stratospheric Aerosol and Gas Experiment (SAGE) II aerosol profiles, which chronicled a 4-month-long perturbation reaching an altitude of $17 \mathrm{~km}$. Yue et al., in accordance with the canonical stratospheric model (and noting that every previous similar observation of SAGE II aerosol perturbation had been associated with a reported volcanic eruption), searched unsuccessfully for a documented volcanic eruption in 1990, and hence concluded that the mystery cloud was attributable to an unreported volcanic eruption in high northern latitudes. In June 1991 Mount Pinatubo's cataclysmic eruption had a global, multiyear impact (e.g., Hansen et al. 1996). Although this event was thoroughly observed and modeled, a perplexing occurrence of early LS aerosol layers in northern middle and high latitudes formed a subtheme in papers on the resultant LS aerosol loading (e.g., Jäger 1992; Gobbi et al. 1992; Trepte and Hitchman 1992). Indeed, there were sufficient SAGE II observations for Thomason (1992) to characterize a "new mode" of "Pinatubo aerosols" just above the tropopause in northern extratropics. According to Thomason (1992), the new mode particle's effective radius was between about 0.27 and $0.36 \mu \mathrm{m}$ (inferred by SAGE II's wavelength dependence of extinction), which was unique in the SAGE volcanic aerosol record and did not conform to expectations for volcanic sulfate droplets (on the order of $1 \mu \mathrm{m}$ ). Moreover, these new mode particles were observed in a systematically different altitude/latitude regime than the expected mode particles-in northern middle-high latitude and just above the tropopause. 
AEROSOL INDEX: THE UNKNOWN SMOKE SIGNAL. Soon after the discovery of stratospheric smoke in 1998, a signal of the immediate effect of violent pyroCb explosions began to take shape. The day after a pyroCb was identified the absorbing aerosol index (AI) sensed by the Total Ozone Monitoring Spectrometer (TOMS) highlighted a smoke plume with peculiarly large AI values (e.g., Fromm et al. 2008a). AI is a positive number in the presence of absorbing aerosols, such as dust, smoke, and ash. AI is strongly dependent on plume aerosol optical depth (AOD) and plume altitude (Torres et al. 1998). At any given time on Earth there are optically opaque absorbing aerosol plumes. For example, in the burning season of Amazonia, perhaps the most familiar biomass-burning region, smoke plumes are often expansive and optically opaque. However, optically thick Amazonian smoke plumes have never had an $\mathrm{AI}>12$ in the TOMS satellite era (TOMS started operating in late 1978 and ended in 2005). In contrast, the "day after" pyroCb smoke plumes of events such as the Chisholm (Alberta, Canada) pyroCb of May 2001 (Fromm et al. 2008a) had AI > 29. In fact, some particularly extreme smoke plumes contain fill/error values in the level-3 (i.e., gridded) AI where the level-2 (i.e., the instrument's native measurement footprint) AI manifests an even greater intensity. Table 1 shows the ranking of $\mathrm{AI}$ in the TOMS era. A listing such as Table 1 is an invaluable tool for investigating causality. Quite simply, it is a matter of looking at satellite image data and weather maps "upstream" one day for a phenomenon that might cause an optically thick, high-altitude smoke plume. Thirteen of the top 20 AI plumes are the results of smoke from documented or otherwise determined pyroCb events. The remaining events are also deep, thick, day-old smoke

\begin{tabular}{|c|c|c|c|c|c|c|}
\hline Al & Plume date & $\begin{array}{l}\text { Lat }\left({ }^{\circ}\right) \\
+N,-S\end{array}$ & $\begin{array}{l}\text { Lon }\left({ }^{\circ}\right) \\
+E,-W\end{array}$ & Cause & Source location & Notes \\
\hline 29.9 & 29 May 2001 & 65 & -112 & pyroCb & Alberta, Canada & $\begin{array}{l}\text { Chisholm Fire; Fromm and } \\
\text { Servranckx (2003) }\end{array}$ \\
\hline 25.9 & 19 Jan 2003 & -32 & 163 & pyroCb & Canberra, Australia & $\begin{array}{l}\text { Pyrotornado; Cunningham } \\
\text { and Reeder (2009) }\end{array}$ \\
\hline 25.3 & 5 Aug 1998 & 73 & -64 & pyroCb & $\begin{array}{c}\text { Northwest Territories, } \\
\text { Canada }\end{array}$ & $\begin{array}{l}\text { Norman Wells pyroCb; } \\
\text { Fromm et al. (2005) }\end{array}$ \\
\hline 18.8 & I8 Aug 2003 & 61 & -89 & pyroCb & $\begin{array}{c}\text { Northwest Territories, } \\
\text { Canada }\end{array}$ & $\begin{array}{c}\text { Conibear Lake Fire; } \\
\text { Wood Buffalo National Park }\end{array}$ \\
\hline 17.9 & 27 Aug 2000 & 42 & -92 & pyroCb & South Dakota & $\begin{array}{c}\text { Jasper Fire; Black Hills } \\
\text { National Forest }\end{array}$ \\
\hline 16.5 & 27 Sep 1998 & 69 & 148 & TBD & Khabarovsk, Russia & \\
\hline 16.2 & 18 Dec 2002 & -35 & 144 & pyroCb & Victoria, Australia & Big Desert Wilderness Park \\
\hline 15.9 & 21 Jun 1991 & 45 & -24 & pyroCb & Quebec, Canada & $\begin{array}{l}\text { Baie-Comeau Fire } \\
\text { (discussed herein) }\end{array}$ \\
\hline 15.6 & 4 May 2003 & 57 & 153 & TBD & Eastern Russia & \\
\hline 15.6 & 10 Jun 2002 & 45 & -101 & pyroCb & Colorado & Hayman Fire \\
\hline 15.4 & 10 Sep 1988 & 46 & -89 & pyroCb & Wyoming & Yellowstone National Park \\
\hline 14.9 & 7 Jul 1990 & 70 & -152 & pyroCb & Alaska & Circle Fire \\
\hline 14.9 & 8 May 1987 & 62 & 133 & TBD & Northern Mongolia & $\begin{array}{l}\text { Great China Fire; } \\
\text { Cahoon et al. (1994) }\end{array}$ \\
\hline 14.4 & 23 Aug 1998 & 49 & 153 & TBD & Khabarovsk, Russia & \\
\hline 14.3 & 27 Jan 2003 & -39 & 168 & TBD & Southeastern Australia & \\
\hline 14.3 & 20 Jun 2002 & 39 & -104 & pyroCb & Arizona & Rodeo-Chediski Fire \\
\hline 14.1 & 19 Jun 2002 & 42 & -99 & pyroCb & Colorado & Hayman Fire \\
\hline 14.0 & 6 May 2003 & 48 & 142 & TBD & Eastern Russia & \\
\hline 14.0 & I Feb 2003 & -28 & -178 & TBD & Southeastern Australia & \\
\hline 14.0 & 19 Aug 2000 & 48 & -107 & pyroCb & Idaho & \\
\hline
\end{tabular}


plumes that have not yet been definitely associated with a specific source or event. Among these there are events in eastern Siberia wherein we suspect a substantial role is played by a vigorous extratropical cyclone spinning up in the flaming zone. This type of investigation, of these and other double-digit AI plumes, led us to a new interpretation of the 1989-91 mystery cloud events.

MYSTERY CLOUD YEAR I: 1989. The August 1989 LS aerosol layers at Salt Lake City reported by SH90 were shown in the context of meteorological analyses and parcel trajectories to be consistent with anticyclonic LS flow between the tropics and midlatitudes. It was in Guatemala that $\mathrm{SH} 90$ found a candidate volcanic eruption consistent in place and time with this LS flow regime. The suspected volcano was Santiaguito, which indeed erupted on 19 July 1989. However, it did not inject material near the stratosphere according to several scientists' eyewitness reports (Smithsonian Institute 1989). We retrieved Geostationary Operational Environment Satellite (GOES) thermal infrared (THIR) imagery from the time of observed eruption $\pm 5 \mathrm{~h}$ and found that the $11-\mu \mathrm{m}$ THIR brightness temperature at the location of Santiaguito attained a minimum value of approximately $-11^{\circ} \mathrm{C}$, which, according to the closest radiosonde, implies a cloud top of no higher than $6 \mathrm{~km}$. Moreover, Bluth et al. (1997) list no volcanic eruptions anywhere as having a volcanic explosivity index (VEI) indicating a stratospheric injection in the second half of 1989.

Fires in Manitoba and Saskatchewan, Canada, in historically great number were ignited by lightning on 17 July 1989 (Hirsch 1991). Four days later, on 21 July, extreme fire-weather conditions led to pyroconvection at a number of these fires, three of which spawned a
pyroCb. GOES imagery (not shown) pinpointed these blowups. Advanced Very High Resolution Radiometer (AVHRR) imagery (Fig. 1a) captured the action in the late afternoon. At least four pulses of deep pyroCb anvils were in evidence. The day-after smoke plume on 22 July contained double-digit AI (Fig. 2a).

Figure 1c shows the smoke plume evolution in the first week after the pyroCb. Evidently the smoke pall is sufficiently high and massive that it can be followed with AI across the Atlantic Ocean to Europe, having a long-range persistence that is similar to other stratospheric smoke episodes (Fromm et al. 2005). We see also that part of the plume was transported south across the United States; the leading edge extended as far as Mexico on 23 July. Remnants of this portion of the plume circulated in the southern United States and Central America. Fortuitously, the smoke plume following this path was sampled by SAGE II on 25 July (Fig. 1b; positions of the SAGE II profiles are marked
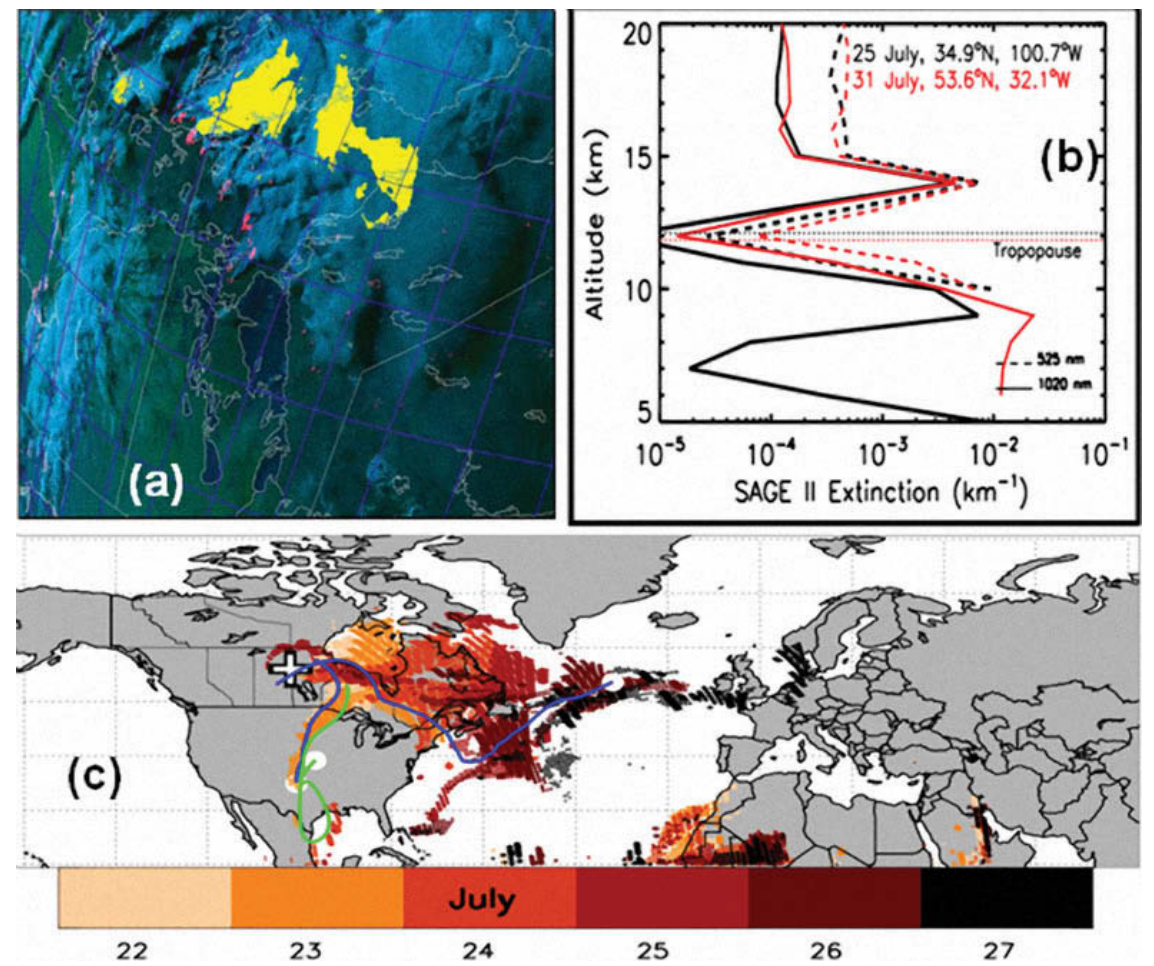

FIG. I. Composite of AVHRR, AI, SAGE II layer, and trajectory for 1989 Manitoba and Saskatchewan, Canada, pyroCbs. (a) AVHRR false-color redgreen-blue (RGB) rendering of 3.7-, 0.86-, and 0.63- $\mu \mathrm{m}$ radiance, respectively, for local evening 2I Jul 1989. Pixels with II- $\mu \mathrm{m}$ IR brightness temperature $<-50^{\circ} \mathrm{C}$ (yellow overlay). (b) Two SAGE II aerosol extinction profiles exhibiting LS layers, on 25 (black) and 3I (red) Jul. Measurements of 1020 (solid lines) and 525 (dashed lines) $\mathbf{n m}$. Locations annotated on plot. Collocated tropopause height (dotted lines). (c) Map of TOMS Al color coded by date, between 22 and 27 Jul 1989. Locations of the two SAGE profiles and the 26 July FIFE lidar measurement are shown (white dots). Pyroconvection location (white + symbol). Back trajectories (solid lines) all start at SAGE (blue line) and lidar (green line) measurement time and end 0000 UTC 22 Jul. 
in Fig. 1c). Figure 1b shows a second SAGE extinction profile measured over the Atlantic on 31 July. Both aerosol profiles exhibit a strong layer at $14-\mathrm{km}$ altitude and a wavelength dependence of extinction illustrative of particles with radii of less than $1 \mu \mathrm{m}$. The back trajectories from both observations make excellent connections with the fire zone on 21-22 July; hence, we have an unambiguous confirmation of stratospheric smoke leading back to this pyroCb event in Canada.

Another fortuitous set of measurements of UTLS aerosols at that time was made in Manhattan, Kansas $\left(39.2^{\circ} \mathrm{N}, 96.6^{\circ} \mathrm{W}\right)$, by ground-based lidar during the First International Satellite Land Surface Climatology Project (ISLSCP) Field Experiment (FIFE) Follow-On Project. The volume-imaging lidar (Eloranta and Forrest 1992) operated between late 26 July and 11 August (http://lidar.ssec.wisc.edu/pub_html/fife/ vil/1989/index.htm). In relation to Topeka, Kansas, we surveyed the entire set of radiosonde temperature profiles and determined that the uppermost backscattering layers on 26 July, 31 July, and 6 August resided demonstrably above the local tropopause (not shown). We ran a back trajectory from the 26 July observation (Fig. 1c), and its path plus endpoint on 22 July are consistent with the plume transport across the United States and its origin in Manitoba, Canada.

A meteorological perspective for the AI, SAGE II, FIFE, and Salt Lake City observations is presented in Fig. 2. Figure 2a shows the day-after AI smoke plume in the context of 22 July geopotential height contours on the $375-\mathrm{K}$ potential temperature surface (representative of the LS aerosol layers reported here and in SH90). The synoptic-scale LS flow regime straddling the smoke plume involves a trough in the middle United States and quasi-zonal flow eastward through Canada. The contour gradient, proportional to wind speed, is in agreement with the rapid southward transport of smoke across the United States into Central America. Figure 2b shows 3.5-day forward trajectories initialized at the time of the AI plume on 22 July, at $14 \mathrm{~km}$, generally representing the various aerosol layers reported here and in SH90. [The Hybrid Single-Particle Lagrangian Integrated Trajectory (HYSPLIT) model (see Draxler and Rolph 2010; available online at http://ready.arl.noaa.gov/ HYSPLIT.phP) is used for trajectories in this paper except where noted otherwise.] The path portrayed by this matrix of particles shows the main features of the multiple paths of AI shown in Fig. 1c. Figure $2 \mathrm{~b}$ also shows a 2-week back trajectory from the earliest $\mathrm{SH} 90$ layer at Salt Lake City. It traces a path back to Central America in the timeframe of the forward movement of the Manitoba smoke plume into that region shown in Figs. 1 and 2. Considering all of the meteorological and aerosol evidence presented here and in SH90 (including the depolarizing nature of the Salt Lake City scatterers), we hold that this reinterpretation of

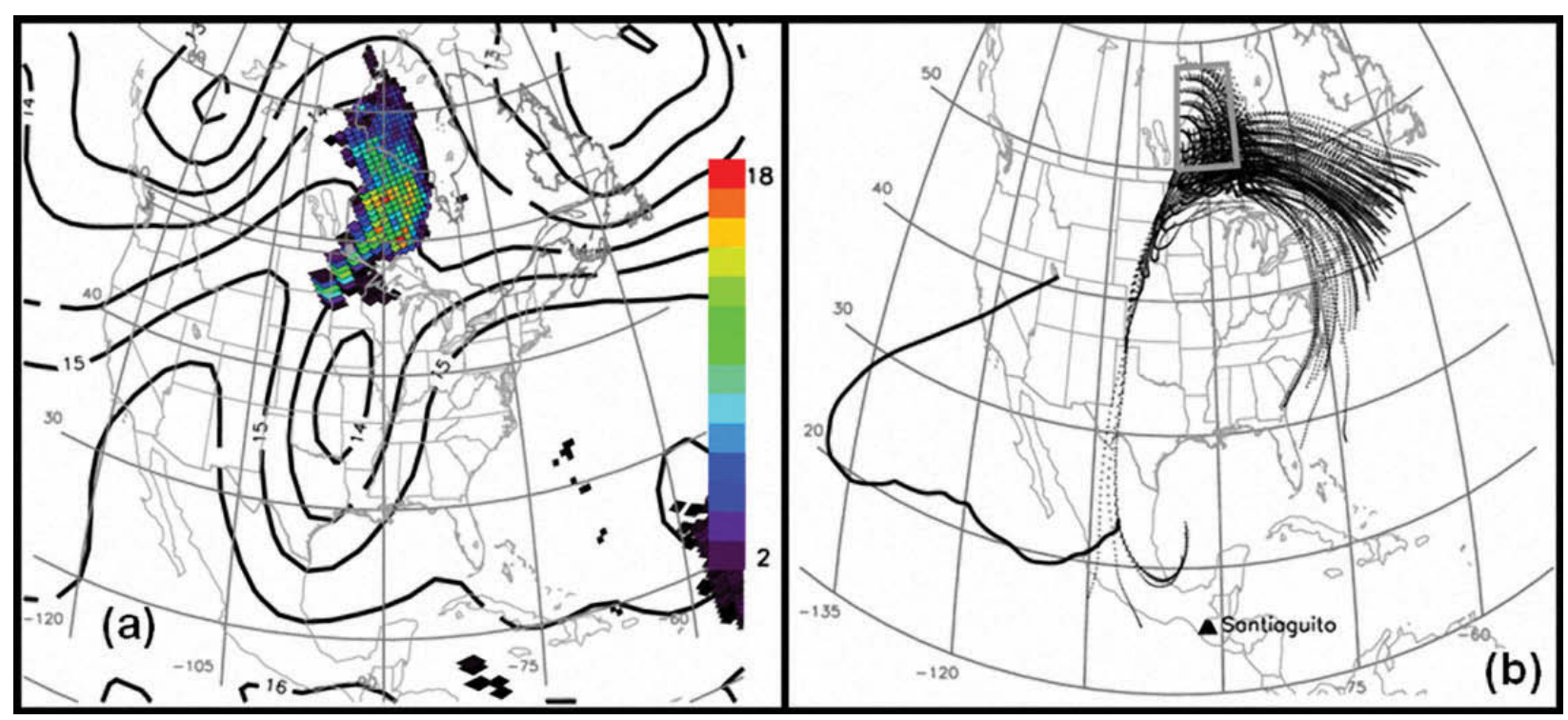

FIG. 2. (a) Geopotential height ( $\mathrm{km})$ on the 375-K potential temperature surface, I200 UTC 22 Jul I989. TOMS Al for 22 Jul 1989 color coded (see color bar) between Al = 2 and 22 Jul maximum Al. (b) Forward trajectories (dotted lines) in a $I^{\circ}$ latitude $\times I^{\circ}$ longitude box representing the Al plume in (a). Trajectories are for $84 \mathrm{~h}$ initiated at 1600 UTC (TOMS measurement time) at $14 \mathrm{~km}$. Also shown is a single $315-\mathrm{h} z=14-\mathrm{km}$ back trajectory initialized at Salt Lake City $\left(40.8^{\circ} \mathrm{N}\right.$, III.8 $\left.\mathrm{W}\right)$ on 0400 UTC 4 Aug 1989. Source for these and all meteorological analyses: the National Centers for Environmental Prediction (NCEP) reanalysis (Kalnay et al. 1996). 
the SH90 conclusions, in terms of LS smoke injected via pyroCb, is convincing. The sporadic measurements of LS aerosol layers provide a conservative hint to the broader stratospheric impact of the July 1989 Manitoba, Canada, pyroCb impact.

\section{MYSTERY CLOUD} YEAR 2: 1990. According to Bluth et al. (1997), there were no volcanic eruptions with stratospheric-level VEI anywhere in 1990 except for Kelut $\left(7.8^{\circ} \mathrm{S}\right)$, Indonesia, in February. However, discovery of a pyroCb in 1990 was afforded by the large AI day-after signal (Table 1). On 7 July 1990 AI $=14.9$ was located over far northern Alaska. Figure 3a shows AVHRR imagery for
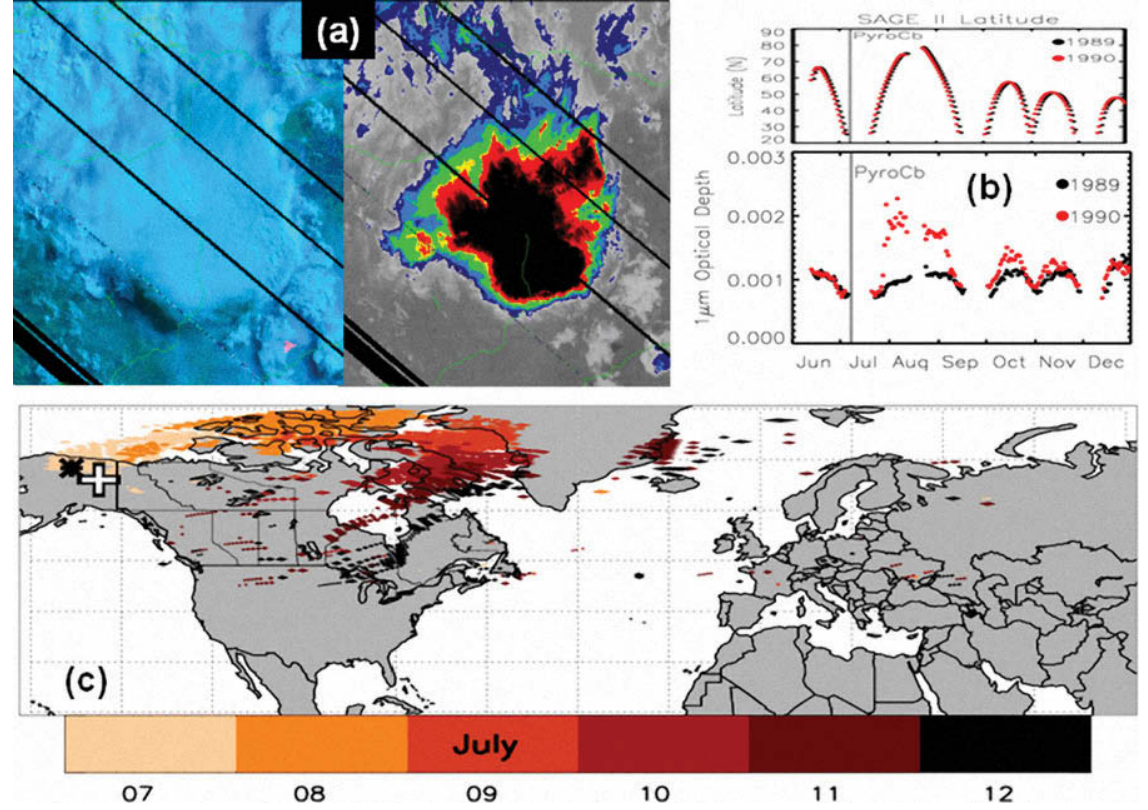

FIG. 3. Composite of AVHRR, AI, and SAGE II AOD for 1990 Circle pyroCb. (a) AVHRR RGB and II- $\mu \mathrm{m}$ BT for morning (I423 UTC) 7 Jul 1990 over northern Alaska. THIR color enhancement for BT $<-40^{\circ} \mathrm{C}$; black is BT < $-57^{\circ} \mathrm{C}$. Minimum BT $=-65.3^{\circ} \mathrm{C}$. (b) SAGE II measurement latitude pattern for (top) 1989 and 1990 and (bottom) daily average LS AOD for Jun through Dec. (c) Map of TOMS Al color coded by date, between 7 and 12 Jul 1990, location of 6 Jul pyroCb (+), and day-after anvil (*). that date and location, ex-

hibiting the classic day-after pyroCb plume signature: an ashy gray cloud in visible bands, and very cold in THIR half-a-day-after injection (Lindsey and Fromm 2008). We then examined GOES visible, 3.9- $\mu \mathrm{m}$ (for hot spots), and THIR image loops and isolated a pyroCb generated by a fire called the Circle Fire, located at $65.9^{\circ} \mathrm{N}, 145^{\circ} \mathrm{W}$, in the afternoon of 6 July. Figure $3 \mathrm{c}$ shows the AI evolution in the week after the pyroCb. The plume drifts north and east over very high Arctic latitudes and then spreads over eastern Canada, the Maritimes, and Greenland. Like the 1989 plume and other pyroCb events, this long-lived and long-transported AI signal represents abundant UTLS smoke aerosols.

Unlike the 1989 pyroCb event, there is no aerosollayer measurement close enough in time to the pyroCb for trajectory-matching analysis. However, Yue et al. (1994) described a large-scale LS SAGE II aerosol perturbation at mid- and high northern latitudes in summer 1990 that, according to their Fig. 2, was still evident in October. We reanalyze the SAGE data in terms of LS AOD, defined as the integration of aerosol extinction from 2 to $6 \mathrm{~km}$ above the tropopause. Figure $3 \mathrm{~b}$ shows zonal average AOD, calculated from a single-day complement of SAGE II profiles. In comparison with that from 1989, the 1990 AOD was identical before the pyroCb but nearly doubled afterward by early August. The plot of SAGE measurement latitude in Fig. $3 \mathrm{~b}$ reveals that the strongest 1990 AOD enhancements were generally in the northernmost SAGE latitudes, indicating a high-latitude source. The anomalous 1990 zonal average AOD exhibits decay but was still evident into November, 4 months after the blowup. We conclude that the true source of this hemispheric LS aerosol increase was the Circle Fire pyroCb on 6 July, not a volcanic eruption. Moreover, a doubling of zonal average LS $\mathrm{AOD}$ is qualitatively equivalent to the perturbation caused by the Canberra, and Chisholm, Australian Capitol Territory, Australia, pyroCbs (Fromm et al. 2006, 2008b).

MYSTERY CLOUD YEAR 3: 1991. Eighth on the list of greatest AI in Table 1 is a smoke plume on 21 June 1991. This plume was located over the Atlantic Ocean northwest of the Iberian Peninsula. One day prior there was also a large AI plume over Newfoundland, Canada. On 19 June there were two pyroCbs in Québec, Canada, spawned by separate fires. One of the fires (Fig. 4a) is about $100 \mathrm{~km}$ west of Baie Comeau, Québec, Canada, as evidenced by the largest/brightest hot-spot cluster; the pyroCb blew up 
after this image. A mature pyroCb with smoke-tinged anvil is present in Fig. 4a north of the Baie Comeau fire. Figure $4 \mathrm{c}$ shows the AI evolution of smoke as the plume rapidly crossed the Atlantic and reached Russia within a week of the blowup. On 22 June the core of the AI plume was situated over northern Europe near Denmark. On that day SAGE II made a measurement slightly east of Denmark (Fig. 4b) that contained a huge aerosol enhancement $2 \mathrm{~km}$ above the tropopause. Indeed, this SAGE measurement was the source of a high AOD feature on a global AOD map illustrating the 24 January 1992 cover of Geophysical Research Letters (1992, Vol. 21, No. 2), an issue that was partly dedicated to first Mount Pinatubo measurements. The back trajectory (Fig. 4c) from the 22 June SAGE II layer implicates the Québec pyroCbs, not those from Mount Pinatubo.

In addition to the SAGE II measurements, a number of lidar measurements in the weeks after the Mount Pinatubo eruption also detected LS aerosols that were difficult to reconcile with the volcano. Figure 5a shows that on 1 July 1991 lidars in Germany (Jäger 1992), France (Chazette et al. 1995), and Italy
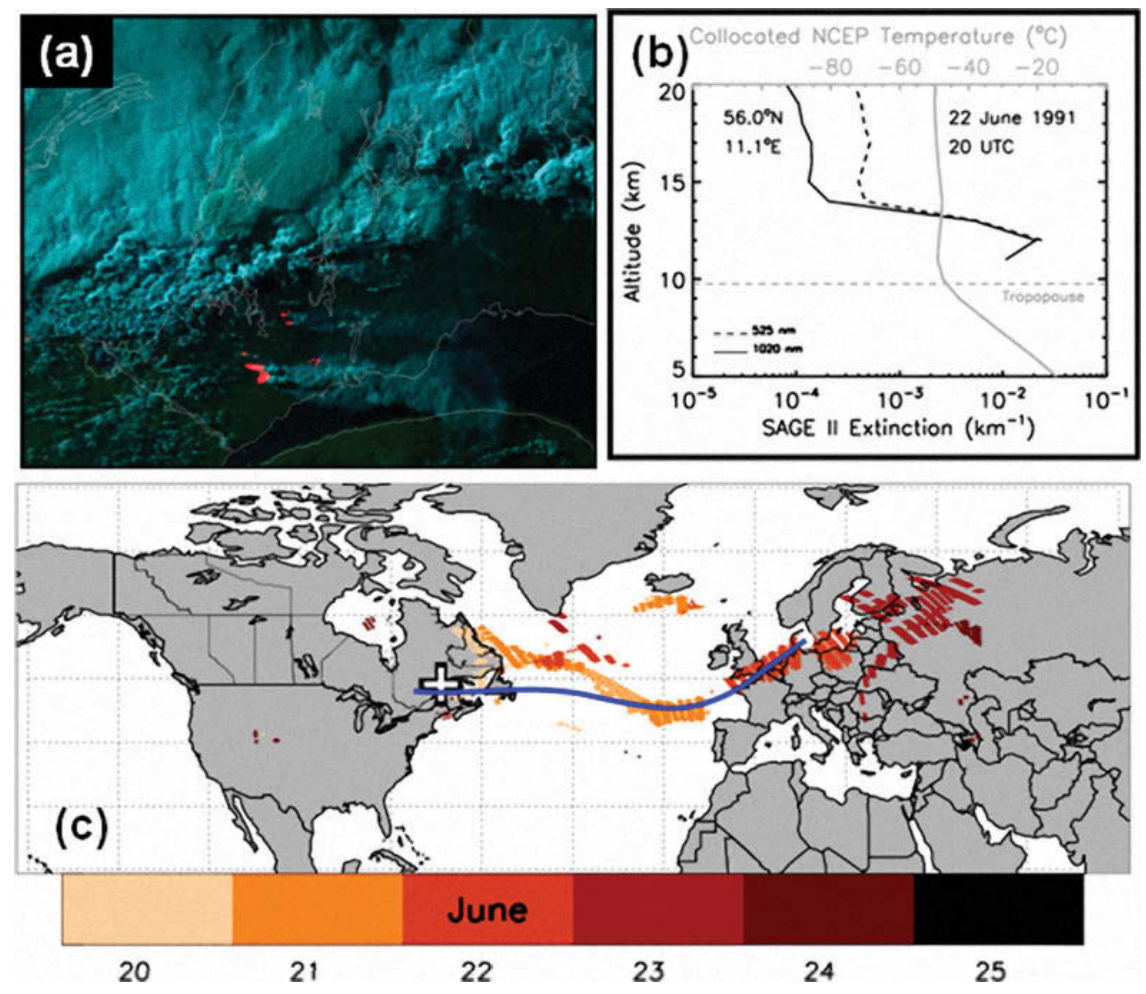

FIG. 4. Composite of AVHRR, AI, SAGE II layer, and trajectory for 199I Quebec, Canada, pyroCbs. (a) AVHRR RGB image for local evening 19 Jun 199 I. (b) SAGE II aerosol extinction and collocated NCEP temperature profile near Denmark on 22 Jun. (c) Map of TOMS Al color coded by date, between 20 and 25 Jun 1991, location of pyroconvection (+), and trajectory (blue line) at SAGE II layer altitude ending 0000 UTC 20 Jun.
(Gobbi et al. 1992) all detected layers at $14-16 \mathrm{~km}$. Back trajectories (Fig. 5b) from these layers all show a path to the 1 July observations from the northwest, across the North Atlantic Ocean, and crossing into North America (two in Canada), back 8-10 days (and within 1 week of the Mount Pinatubo eruption). Figure 6 shows a time series of the 313-nm backscatter coefficient recently calculated from measurements with the ozone lidar at Garmisch-Partenkirchen, Germany, on 1-3 July 1991 (Carnuth et al. 2002). These data reveal very high backscatter values in the lower stratosphere between 13 and $16 \mathrm{~km}$ during two specific periods, but much less in the evening of 1 July when the $532-\mathrm{nm}$ measurement in Fig. 5 was made. The peak backscatter coefficient reached $8 \times$ $10^{-6} \mathrm{~m}^{-1} \mathrm{sr}^{-1}$. The strong backscattering is indicative of a young (on the order of days old) and concentrated mass of aerosols. We calculated one hundred and eleven 315-h backward trajectories for this episode at intervals of $3 \mathrm{~h}$, starting at altitudes between 13.5 and $16 \mathrm{~km}$ over Garmisch-Partenkirchen. Trajectories from the two relatively strong plumes closely pass over southeastern Québec (not shown). All of the trajectory paths can be generally characterized as westerly; endpoints (between 17 and 19 June) ranged from the western Atlantic Ocean through Central and North America to the eastern Pacific Ocean. The characteristic path of air reaching these three lidar sites is thus entirely inconsistent with the Mount Pinatubo plume, the direction of movement of which was westward from the eruption and constrained within $20^{\circ}$ latitude of the equator (Bluth et al. 1992).

Thus, it appears that the pyroCb mechanism offers a reinterpretation for part of the widespread aerosol pollution of the northern LS in the summer of 1991, as well as the mystery clouds in 1989 and 1990. This reinterpretation has implications for how stratospheric aerosol processes and the effect of 
extratropical convection on the UTLS are handled in transport, chemical, and climate models.

HOW FREQUENT ARE PYROCBS? The lesson of the prior discussion includes a realization that pyroCb occurrence is both greater than expected and a previously unknown contributor to historical smoke plume events. It is also reasonable to conclude that, like "regular" cumulonimbus, pyrocumulonimbus vary in intensity from the relatively rare, deepest stratospheric polluters to more frequent storms of lesser vertical extent. We explore these issues here, where we focus on one season, that of 2002, in North America. Much of southwestern United States experienced particularly intense drought in 2002 (Quiring and Goodrich 2008). During that season, a Canadian pyroCb was shown to be the source for in situ measurements of biomass-burning tracers in the LS (Jost et al. 2004). However, Jost et al. also came to the conclusion that deep pyroconvective activity was also likely to have occurred in the western United States that summer. Partly aided by the TOMS AI record, we surveyed the period of May-September 2002 for other UTLS smoke plumes and pyroconvection.

FIRE SEASON 2002. Figure 7 shows how daily AI extremes for a fixed geographic area vary with time. Interpreting the spikes as a possible signal of a particularly intense and high smoke plume, we identify candidate events to explore more deeply. Note that the spikes of interest need not be double-digit values of the historically greatest plumes of Table 1; any sharp day-to-day AI increase is a clue to a story worth exploring. It is of course also expected that some noteworthy plumes may be "hidden" among other more intense AI signals over an area as large as North America. Hence, Fig. 7 probably underestimates the number of events because one AI spike may be the result of more than one pyroCb. We investigated the AI spike events (AI $>5)$ by noting the date/coordinates of the plume, evaluating back trajectories from that location, examining GOES imagery "upstream" on the prior date, and searching fire databases to confirm
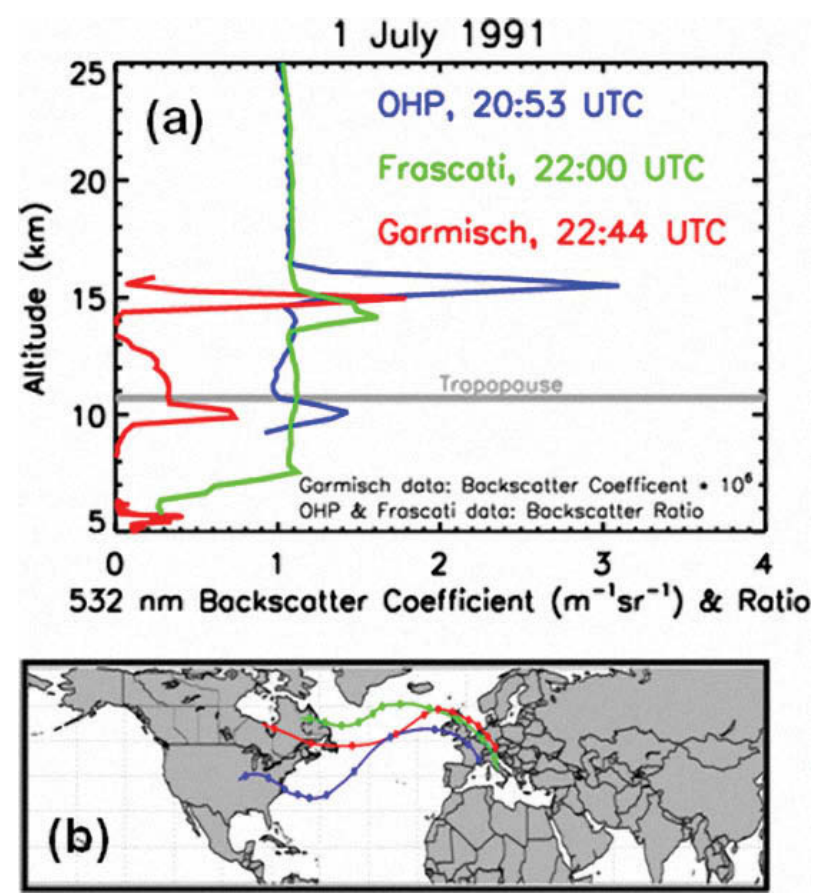

FIG. 5. Three European aerosol lidar profiles on I Jul 199I, and back trajectories. Locations are GarmischPartenkirchen, Germany $\left(47.5^{\circ} \mathrm{N}, \mathrm{II} . \mathrm{I}^{\circ} \mathrm{E}\right)$; Haute Provence Observatory (OHP), France $\left(44.0^{\circ} \mathrm{N}\right.$, $\left.6.0^{\circ} \mathrm{E}\right)$; and Frascati, Italy $\left(41.8^{\circ} \mathrm{N}, 12.7^{\circ} \mathrm{E}\right)$. (a) Garmisch data are 532-nm backscatter coefficient $\left(\mathrm{m}^{-1} \mathrm{sr}^{-1}\right)$ scaled by $10^{6}$. Frascati and OHP data are 532-nm backscatter ratio, that is, (aerosol + Rayleigh)/Rayleigh. Tropopause height averaged from radiosonde profiles nearest the lidars. (b) Isentropic back trajectories from LS aerosol layers beginning at 2200 UTC I Jul and ending at 2200 UTC 20 Jun. Dots at 0000 UTC. Trajectory model described by Schoeberl and Sparling (1995). Credit for data access: NASA Goddard Automailer.

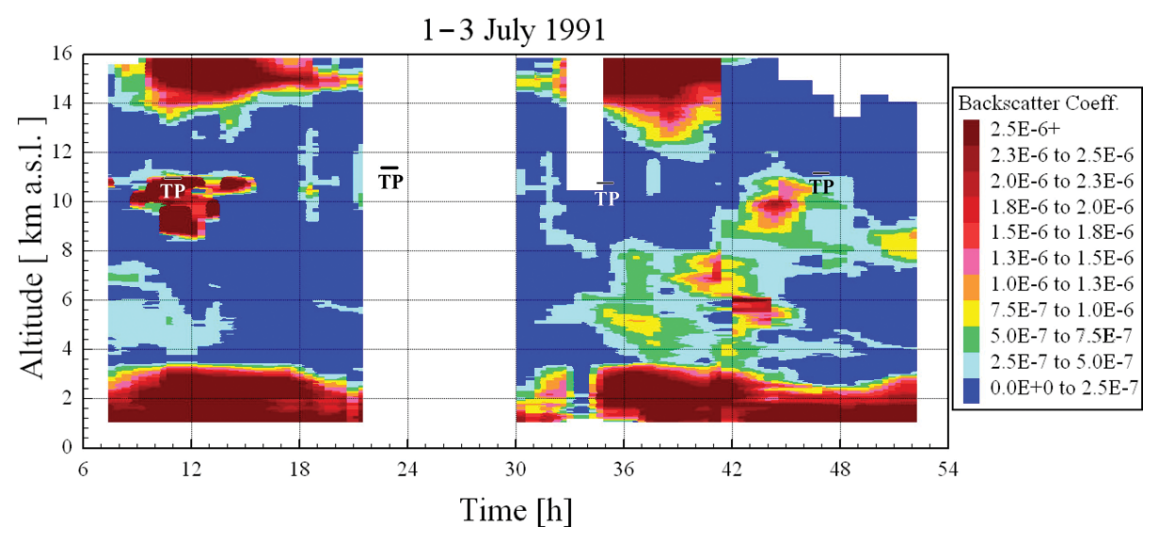

FIG. 6. Color-coded time series of the 3I3-nm backscatter coefficient derived from lidar measurements at Garmisch-Partenkirchen on I-3 Jul 199I; the time is given in central European time $(C E T=U T C+I \mathrm{~h})$. Tropopause height from Munich radiosondes annotated as black horizontal line segments over “TP." Whiteout areas indicate there are no measurements (2200-2900 CET) or data evaluation is not possible (e.g., due to clouds). 


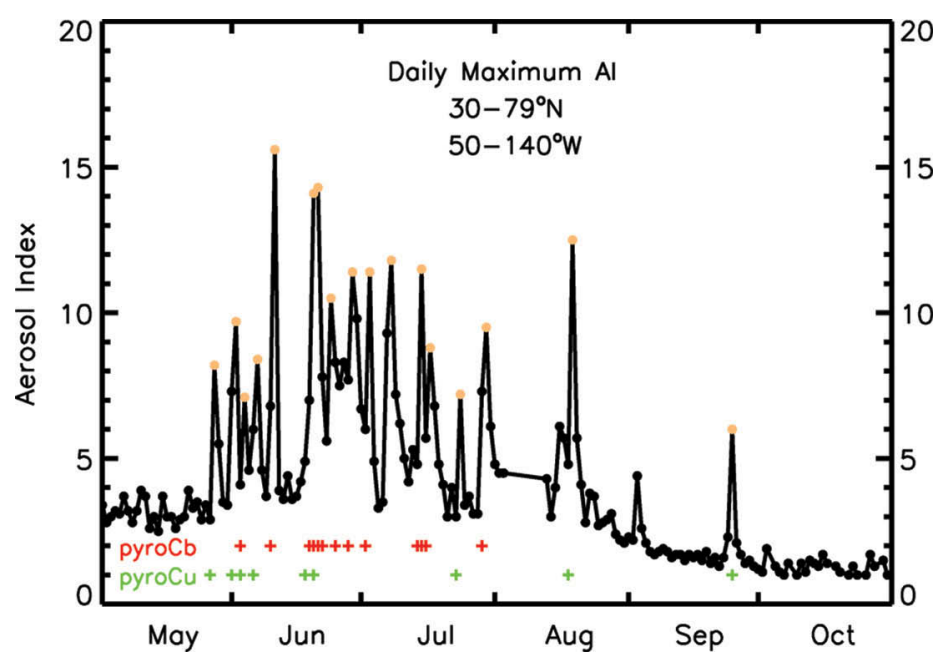

FIG. 7. Daily maximum NASA TOMS aerosol index over North America, May-Oct 2002. Isolated spikes with values $>5$ are capped with a brown dot. Annotations for dates of pyroCu and pyro $\mathrm{Cb}$ events.

fire location. For U.S. fires we used a compilation of Incident Status Summary (ICS-209) reports maintained by the U.S. Forest Service (C. McHugh 2009, personal communication). For Canada, we used the Large Fire Database (LFDB; Stocks et al. 2002). Pyrocumulus (pyroCu) convection is considered to have occurred if the short-wavelength infrared (SWIR; $3.9 \mu \mathrm{m}$ ) GOES imagery contains fire hot spots and if THIR imagery shows clouds, anchored to the hot spots, with colder-than-land brightness temperature (BT); "dry" smoke plumes are transparent to THIR radiation. The pyroCb subclass of pyroCu is indicated when the fire-anchored cloud pixels have $\mathrm{BT}<-40^{\circ} \mathrm{C}$. The likelihood of pyroCb detection is increased by using the SWIR image of the fire-anchored cold (in THIR) cloud, which in daylight conditions will emit as an anomalously high BT $\left(+10^{\circ} \mathrm{C}\right.$ or more $)$ owing to the peculiarly small particle size within smoky pyroCb anvils (Lindsey and Fromm 2008).

\section{PYROCONVECTION IN 2002.}

Table 2 gives a listing of the 2002 pyroCbs and "smoking gun" fires discovered by this method. Figure 8 is a map of fires $>200 \mathrm{ha}$, pyroCu, pyroCb, and the AI spikes highlighted in Fig. 7. The dates of the pyroCu and pyroCb events are annotated on Fig. 7, which shows that from 1 to 25 May, daily maximum
AI was relatively low and invariant. AI in October was similarly invariant and small, consistent with light/declining wildfire activity. However, starting on 26 May the AI spike frequency increases strongly and remains the dominant feature through July. On 9 days between June and August, maximum AI reaches double-digit values. The first spike in May is attributable to a complex of fires and pyroconvection in eastern Alberta, Canada. Here the pyroCu cloud tops reached a (GOES) BT of $-22^{\circ} \mathrm{C}$, which according to the nearest radiosonde gives height and pressure of $5.9 \mathrm{~km}$ and $470 \mathrm{hPa}$, respectively. More pyroCu were detected in Alberta, Canada, on 31 May with upper-tropospheric cloud-top heights. Between 2 June and 28 July we identified 17 pyroCbs, 9 of which were in the 2 -week period 18 June and 1 July. Noteworthy among these are the Hayman Fire in Colorado, which erupted into a pyroCb within 1 day of being ignited and a second time on 18 June, and the Rodeo-Chediski fire complex in Arizona. These were the two largest fires in the history of these two states and both were anthropogenic (Graham 2003; Ffolliott et al. 2008). On one occasion, 2 June, pyroconvection and two pyroCbs erupted from three separate fires along the Colorado/New Mexico border. One of these fires (named "unknown") was not included in the U.S. Forest Service fire database. On four consecutive days between 18 and 21 June, pyroCbs exploded in Arizona, Colorado, and Alberta, Canada. On three consecutive days in mid-July, pyroCbs were found in Colorado and
Fires > 200 ha, pyroCu, pyroCb, \& Al Spikes, 2002

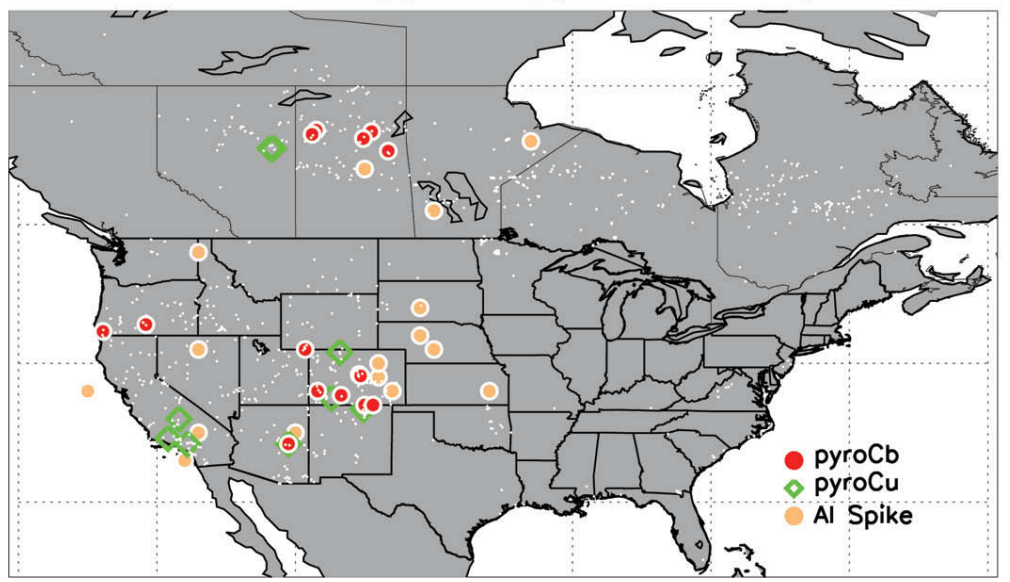

Fıg. 8. Map of 2002 pyroCu (green diamonds), pyroCb (red-filled circles), and Canada/U.S. fires $>200$ ha (white dots). Also plotted are locations of the Al spikes highlighted in Fig. 7. 
Oregon. Two of these were generated by a single fire, the Burn Canyon Fire, roughly $24 \mathrm{~h}$ apart.

PyroCbs are obviously an extreme form of convection, yet their favored environmental conditions differ from those necessary for severe thunderstorms. Table 2 contains two stability measures for the 2002 pyroCbs: convective available potential energy (CAPE; see Bluestein 1993) and the Lower Atmospheric Severity Index (LASI) for wildland fires, better known as the Haines index (Haines 1988). There is no single CAPE threshold for severe convection; however, it is usually associated with values exceeding $\sim 1000 \mathrm{~J} \mathrm{~kg}^{-1}$, which typically implies a conditionally unstable lapse rate combined with abundant lower-tropospheric water vapor. In contrast, the Haines index (online at http://rammb. cira.colostate.edu/visit/fire/haines2.asp for details), which also includes a lapse-rate and moisture term,

\begin{tabular}{|c|c|c|c|c|c|c|c|c|}
\hline $\begin{array}{l}\text { Name } \\
\text { (Final size, ha) }\end{array}$ & Date & $\begin{array}{l}\text { Lat } \\
\left({ }^{\circ} \mathrm{N}\right) \\
\end{array}$ & $\begin{array}{l}\text { Lon } \\
\left({ }^{\circ} \mathrm{W}\right)\end{array}$ & $\begin{array}{l}\text { BTmin } \\
\left({ }^{\circ} \mathrm{C}\right)\end{array}$ & $\begin{array}{r}\text { Cloud-top z } \\
(\mathrm{km}) / \mathrm{p}(\mathrm{hPa})\end{array}$ & $\begin{array}{c}\text { LCL z (km)/ } \\
\text { P (hPa) }\end{array}$ & $\begin{array}{l}\text { Haines index } \\
\text { (J)/ CAPE (kg) }\end{array}$ & $\begin{array}{l}\text { RAOB } \\
\text { site }\end{array}$ \\
\hline $\begin{array}{l}\text { Spring } \\
(6,677)\end{array}$ & 2 Jun & 37.0 & 105.0 & -43.0 & $10.4 / 267$ & $5.2 / 544$ & $6 / 583$ & $A B Q$ \\
\hline Unknown & 2 Jun & 37.0 & 104.4 & -52.0 & $10.4 / 267$ & $5.2 / 544$ & $6 / 583$ & $A B Q$ \\
\hline $\begin{array}{l}\text { Hayman } \\
(55,749)\end{array}$ & 9 Jun & 39.2 & 105.4 & -56.1 & $12.3 / 200$ & $6.1 / 483$ & $6 / 92$ & DNR \\
\hline $\begin{array}{l}\text { Hayman } \\
(55,749) \\
\end{array}$ & 17 Jun & 39.2 & 105.4 & -56.2 & $11.6 / 222$ & $4.9 / 561$ & $6 / 918$ & DNR \\
\hline $\begin{array}{l}\text { Hayman } \\
(55,749)\end{array}$ & 18 Jun & 39.1 & 105.3 & -53.1 & $11.5 / 225$ & $6.3 / 490$ & $6 / 0$ & DNR \\
\hline $\begin{array}{l}\text { Million } \\
(3,782)\end{array}$ & 19 Jun & 37.7 & 106.7 & -58.0 & $12.2 / 200$ & $5.5 / 519$ & $6 / 287$ & GJT \\
\hline $\begin{array}{l}\text { Rodeo/Chediski } \\
(\mid 89,65 I)\end{array}$ & 20 Jun & 34.2 & 110.5 & -44.1 & $10.2 / 270$ & $5.1 / 559$ & $6 / 0$ & FGZ \\
\hline $\begin{array}{l}\text { Dobbin } \\
(151,640)\end{array}$ & 21 Jun & 56.7 & 104.5 & $-58 . I^{*}$ & II.8/207 & $2.5 / 760$ & $6 / 135$ & YQD \\
\hline $\begin{array}{l}\text { Meadow } \\
(75,483)\end{array}$ & 24 Jun & 56.8 & 108.5 & -44.1 & $9.5 / 290$ & $2.2 / 782$ & $5 / 0$ & YSM \\
\hline $\begin{array}{l}\text { Lobb } \\
(62,171)\end{array}$ & 27 Jun & 55.3 & 103.3 & -58.0 & $12.4 / 187$ & $2.5 / 762$ & $5 / 0$ & YQD \\
\hline $\begin{array}{l}\text { Nagle } \\
(71,029)\end{array}$ & 27 Jun & 56.2 & 105.1 & -61.0 & $12.8 / 182$ & $2.5 / 762$ & $5 / 0$ & YQD \\
\hline Unknown & 27 Jun & 56.5 & 108.8 & $-58.0 *$ & $12.2 / 197$ & $1.7 / 819$ & $4 / 11$ & YSM \\
\hline $\begin{array}{l}\text { Mustang } \\
(8,109)\end{array}$ & I Jul & 41.0 & 109.3 & -60.0 & $13.0 / 184$ & $4.1 / 623$ & $6 / 18$ & SLC \\
\hline $\begin{array}{l}\text { Burn Canyon } \\
(12,667)\end{array}$ & $13 \mathrm{Jul}$ & 38.0 & 108.4 & -53.1 & $11.9 / 216$ & $6.0 / 494$ & $6 / 768$ & GJT \\
\hline $\begin{array}{l}\text { Burn Canyon } \\
(12,667)\end{array}$ & I4 Jul & 38.0 & 108.4 & -53.1 & $12.6 / 193$ & $5.5 / 532$ & $6 / 420$ & GJT \\
\hline $\begin{array}{l}\text { Winter } \\
(14,479)\end{array}$ & I5 Jul & 42.8 & 120.8 & -43.1 & $10.7 / 258$ & $3.6 / 672$ & $6 / 0$ & BOI \\
\hline $\begin{array}{l}\text { Florence/Biscuit } \\
(202,169)\end{array}$ & $28 \mathrm{Jul}$ & 42.3 & 123.9 & -50.2 & $11.6 / 232$ & $2.4 / 770$ & $6 / 0$ & MFR \\
\hline Average & & & & & $11.6 / 223$ & $4.19 / 628.0$ & & \\
\hline
\end{tabular}

* BTmin < RAOB Tmin 
signals extreme fire behavior only when an unstable lapse rate is matched with a dry lower troposphere, that is, a classic "inverted V" profile. In the case of the 17 pyroCbs in Table 2, CAPE values were indeed relatively small, with roughly half of the cases having a value of zero. However, the Haines index registered its maximum value of 6 (indicating conditions for high rate of fire spread) for all of the pyroCbs in the United States and one out of five in Canada. Of the remaining Canadian pyroCbs, all but one had a Haines index of 5.

In addition to a favorable Haines index, pyroCbs, like most cumulonimbus, also need a trigger for initiation. Sometimes the heat and moisture from the fire itself is sufficient for initiation, but occasionally the midlevel stability is too great for parcels to reach their level of free convection, and pyroCbs do not form. One trigger noted with fire blowups and pyroCbs is a cold front passage (e.g., Westphal and Toon 1991; Fromm et al. 2005). Luderer et al. (2006) modeled a documented pyroCb environment associated with a frontal passage and found that the modeled pyroconvection was substantially influenced by a cold front.

Perhaps fire size is an important metric for predicting pyroCbs. Table 2 lists the final fire size for the "smoking guns." They were all large fires, but the final burned-area perimeter varies by two orders of magnitude. We did not have access to time-resolved fire-size change for Canada fires; this would be a critical value to have to associate fuel consumed on the days of pyroconvection versus the other days in the fire's lifetime.

STRATOSPHERIC SMOKE IN 2002. In addition to the stratospheric impact Jost et al. (2004) reported from Canadian fires (on 27 June), there is strong evidence of stratospheric smoke from three additional pyroCbs: Hayman (9 June), a pyroCb ensemble between 18 and 20 June in Colorado-Arizona, and the Mustang pyroCb on 1 July (D. Knapp et al. 2009, personal communication). The evidence is from satelliteand ground-based aerosol profiles. For instance, on 21 June, the Purple Crow lidar (Sica et al. 1995) in London, Ontario, Canada, $42.9^{\circ} \mathrm{N}$, $81.4^{\circ} \mathrm{W}$, detected an aerosol layer between 11.6- and 14.5-km altitude, straddling the tropopause at $13.3 \mathrm{~km}$ (Fig. 9). An isentropic back trajectory passes over Colorado close to the Hayman fire on 18 June, the site of a second pyroCb from this fire (Table 2). This supports the contention of Jost et al. (2004) regarding additional occurrences of deep pyroconvection impacting the UTLS in 2002.

\section{PYROCB INJECTION ALTITUDE. It is abun-} dantly evident, considering the published reports of stratospheric pollution via the pyroCb, that the effective maximum height of a pyroCb's outflow is at or above the convective cloud-top altitude. A conventional method by which to infer cloud-top height (for optically opaque clouds such as thunderstorm anvils) is by way of cloud-top thermal infrared brightness temperature matched against the environmental lapse rate (Smith and Platt 1978). Even though this method entails uncertainty for clouds in the tropopause region resulting from potential nonsingularity in the temperature-height profile, it can still provide a robust, albeit conservative, value for outflow height. We employed this method for the events in Table 2. The average resulting pyroCb cloud-top altitude and pressure are $11.6 \mathrm{~km}$ and $223 \mathrm{hPa}$, respectively.

DIURNAL PYROCB BEHAVIOR. Of all the factors that influence wildfire behavior, meteorology plays a big role. A strong feature of wildfire behavior is a diurnal cycle of alternation between nighttime relative quiescence and afternoon peak burning activity, driven by surface temperature, relative humidity, and wind speed. These fire-weather factors are basic inputs to the Fire Weather Index (FWI) component to the Canadian Forest Fire Danger Rating System

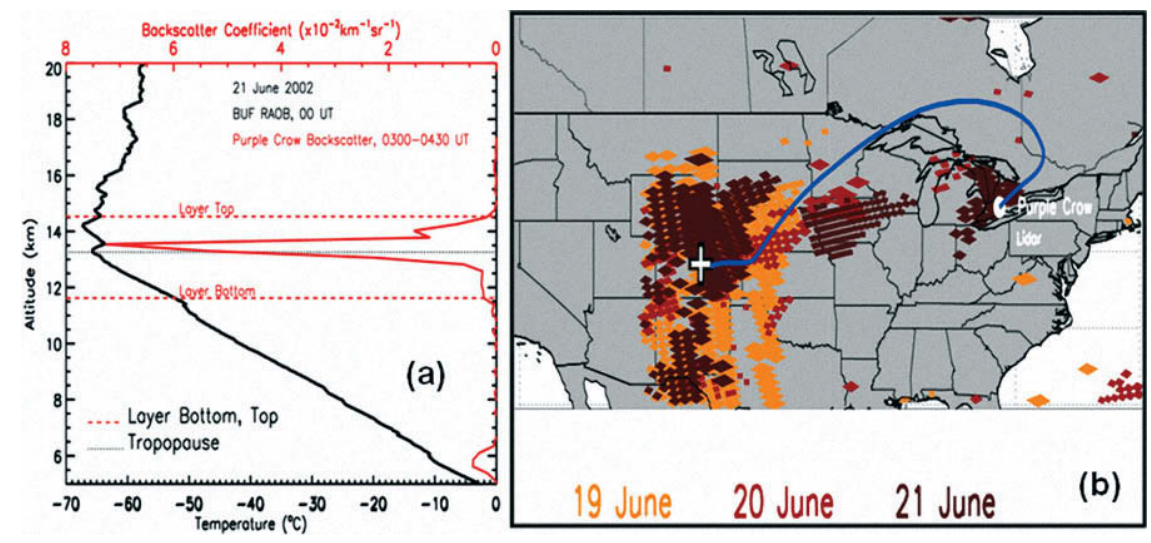

Fıg. 9. (a)Purple Crow lidar aerosol backscatter, 21 Jun 2002 and Buffalo radiosonde temperature profile, 0000 UTC 21 Jun. (b) Back trajectory superimposed on the AI map as in Fig. I, with white dot showing lidar location. Back trajectory $Z=13 \mathrm{~km}$; endpoint is $0000 \mathrm{UTC} 19 \mathrm{Jun}$. 
(Amiro et al. 2004, and references therein). It is therefore important to characterize a typical day in the life of a pyroCb, not only to understand the fire and firestorm behavior, but also to characterize the time change of emission height. This knowledge will inform fire behavior analysts, users of satellite data, and modelers. Since the discovery of the pyroCb, they have been observed by satellite to occur in morning, afternoon, and in middle-of-the-night hours. Even in 2002, among the 17 pyroCb events identified, one occurred at approximately 1100 LT (the Meadow Fire pyroCb on 24 June) and one occurred near local midnight (Burn Canyon, on 13 July). However, the preponderance of pyroCbs reached maturity in late afternoon, around $1800 \mathrm{LT}$ (Table 2). We have analyzed all 17 in terms of local time, using GOES IR imagery to identify fire growth, pyrocumulus onset, and maturity. Here we centered each fire in a grid of GOES pixels approximately $48 \mathrm{~km}$ on a side and recorded certain metrics at each image time, for example, the maximum 11- $\mu \mathrm{m} \mathrm{BT} \mathrm{(BTmax)} \mathrm{and}$ minimum 11- $\mu \mathrm{m} \mathrm{BT} \mathrm{(BTmin).} \mathrm{The} \mathrm{BTmin} \mathrm{metric} \mathrm{is}$ generated with respect to radiosonde-derived lifted condensation level (LCL) temperature. Negative values suggest pyrocloud formation; the more negative the value, the higher the pyrocloud. Fire hot-spot size change is tracked with $3.9-\mu \mathrm{m} \mathrm{BT}$. A qualitative fire-size index is formed by counting hot-spot pixels and dividing by the maximum hot-spot count for that fire/pyroCb.

Figure 10 presents the average over all 17 pyroCb events. The fire-size metric shows that before local noon, fire size is negligible, consistent with the general diurnal behavior of tropical and subtropical vegetation fire (Giglio 2007). Toward midday, fire size increases and peaks in early afternoon. Undoubtedly this metric is impacted by cloud formation and is thus not solely influenced by fire behavior. However, in the mean it is apparent that these fires that erupted into pyroCbs spent the first half of the day being relatively inactive.

The BTmax trace, which likely represents clear-sky pixels, shows morning warming and a peak around 1300 LT. The BTmin curve generally follows BTmax until 1100 LT, when it peaks and begins a steep decline. This signifies the onset of pyroconvection wherein cloud formation in the flaming area begins to modify the diurnal clear-sky radiance progression. At roughly 1330 LT BTmin becomes negative, effectively indicating that an optically thick pyrocumulus cloud fills a GOES $4 \mathrm{~km}^{2}$ pixel. Thus, at this point, the emissions from the fire may be assumed to reach as high as the LCL, which on average here is $4.1 \mathrm{~km}$

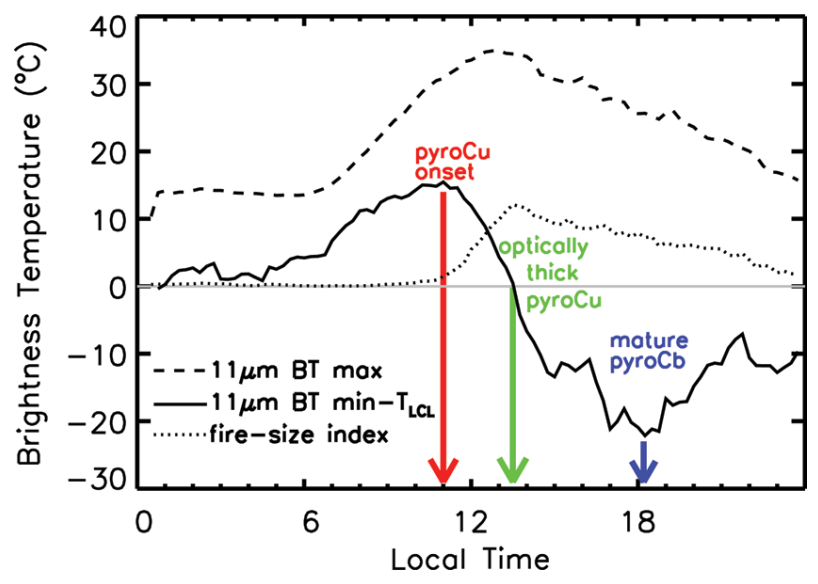

Fig. 10. Average diurnal cycle for fire and pyrocloud for 17 pyroCb events in 2002 . See text for pixel box used. Dotted line is the fire-size index (unitless, scaled for viewing clarity; see text for details). The II- $\mu \mathrm{m}$ BT maximum is shown in the box (dashed line); the II- $\mu \mathrm{m}$ BTmin LCL temperature is the solid black line.

$(632 \mathrm{hPa})$. From this point pyroconvection intensifies steadily (in the average sense) until a peak at roughly 1800 LT, when the pyroCb can be considered in full maturity. At this point the pyroCb is exhausting a considerable amount of biomass-burning emissions in the UTLS.

Thus, in the typical diurnal cycle of fire behavior that includes pyroCb energy, it can be expected that exhaust from this fire will span the troposphere in the course of a day. It is reasonable then to conclude that a considerable proportion of the emissions during the hours of deepest pyroconvection will be injected into the uppermost troposphere, above precipitation/ scavenging processes. This is indeed a fundamental reinterpretation of fire vertical injection potential that is not well characterized in regional or global atmospheric models of chemistry and transport.

SUMMATION. Since the discovery of smoke in the stratosphere and the pyroCb, only a small number of individual case studies and modeling experiments (Trentmann et al. 2006; Luderer et al. 2006; Cunningham and Reeder 2009) have been performed. Hence, there is still much to be learned about the pyroCb and its importance. With this work we have attempted to reduce the unknowns by revealing several additional occasions when pyroCbs were either a significant or sole cause for the type of stratospheric pollution usually attributed to volcanic injections. Now it is established that pyroCb activity is sufficiently frequent that a measurable stratospheric increase in aerosols attributable to this process occurred in 1989-91, 1992 (Livesey et al. 
2004), 1998 (Fromm et al. 2000, 2005), and 2001-04 (Fromm et al. 2006, 2008a,b; Cammas et al. 2009). Unpublished analyses of satellite data (e.g., SAGE II aerosol profiles and imager data) have also revealed pyroCbs and stratospheric aerosol layers that are attributable to the Great China Fire in May 1987 (Cahoon et al. 1994) and the Yellowstone fires of 1988 (Alexander 2009). Hence, it can be concluded that for six consecutive years (1987-92) the pyroCb phenomenon was present and its stratospheric impact was identifiable. As research continues, the characterization of stratospheric impact attributed to the pyroCb will be further refined.

On an intraseasonal level we have established that pyroCbs occur with surprising frequency. In 2002, at least 17 pyroCbs erupted in North America alone. Still to be determined is how often this process occurred in the boreal forests of Asia in 2002. However, it is now established that this most extreme form of pyroconvection, along with more frequent pyrocumulus convection, was widespread and persisted for at least 2 months. The characteristic injection height of pyroCb emissions is the upper troposphere, and a subset of these storms pollutes the lower stratosphere. Thus, a new appreciation for the role of extreme wildfire behavior and its atmospheric ramifications are now coming into focus.

Considering these now-told stories of pyroCb behavior, it is quite likely that future blowups will permit continued study of these events as they unfold. Satellite imagery and data such as those shown herein are indispensable for such analyses. We consider it very important to note the continued need for global monitoring by nadir-viewing imagers and stratospheric monitoring by instruments such as NASA's Cloud-Aerosol Lidar and Infrared Pathfinder Satellite Observation (CALIPSO; e.g., Thomason et al. 2007). Satellite data were the true source for the discovery of pyroCbs and smoke in the stratosphere; their value toward future studies and discoveries is inestimable.

ACKNOWLEDGMENTS. Level-2 TOMS aerosol index data were provided by the NASA TOMS team. We thank Peter Englefield for Canada fire-location data, and Chuck McHugh for U.S. Forest Service fire data. We also thank Gian Paul Gobbi and the ISAC-CNR Rome group for Frascati lidar data, and Horst Jäger for the GarmischPartenkirchen aerosol lidar data. The Haute Provence lidar data are from the Network for the Detection of Atmospheric Composition Change (NDACC) and are available online (www.ndacc.org). Radiosonde-derived data were accessed online (http://weather.uwyo.edu/upperair/sounding.html), as was the SPARC Data Center (www.sparc.sunysb.edu/ html/hres.html). The authors gratefully acknowledge the NOAA/Air Resources Laboratory (ARL) for the provision of the HYSPLIT transport and dispersion model and/or READY Web site (www.arl.noaa.gov/ready.html) as well as NOAA's Comprehensive Large Array-Data Stewardship (CLASS; online at www.class.ncdc.noaa.gov/saa/products/ welcome) for satellite data used in this publication. The Goddard Automailer interface was also used for trajectory calculations. Pat Kablick provided valuable help improving the manuscript. MDF was supported by NRL internal funding (from the Office of Naval Research). The views, opinions, and findings in this report are those of the authors, and should not be construed as an official NOAA and or U.S. Government position, policy, or decision.

\section{REFERENCES}

Alexander, M., 2009: The 1988 fires of Yellowstone and beyond as a wildland fire behavior case study. USDA Forest Service, Wildland Fires Lessons Learned Center, 30 pp. [Available online at www. wildfirelessons.net/documents/Alexander_Yellowstone88_FB.pdf.]

Amiro, B., K. Logan, B. M. Wotton, M. Flannigan, J. Todd, B. Stocks, and D. Martell, 2004: Fire weather index system components for large fires in the Canadian boreal forest. Int. J. Wildland Fire, 13, 391-400.

Andreae, M., D. Rosenfeld, P. Artaxo, A. Costa, G. Frank, K. Longo, and M. Silva-Dias, 2004: Smoking rain clouds over the Amazon. Science, 303, 1337-1342.

Bluestein, H. B., 1993: Observations and Theory of Weather Systems. Vol. 2, Synoptic-Dynamic Meteorology in Midlatitudes, Oxford University Press, 594 pp.

Bluth, G. J. S., S. Doiron, C. Schnetzler, A. Krueger, and L. Walter, 1992: Global tracking of the $\mathrm{SO}_{2}$ clouds from the June, 1991 Mount Pinatubo eruptions. Geophys. Res. Lett., 19, 151-154.

—, W. I. Rose, I. E. Sprod, and A. J. Krueger, 1997: Stratospheric loading from explosive volcanic eruptions. J. Geol., 105, 671-683.

Browell, E. V., and Coauthors, 1990: Airborne lidar observations in the wintertime Arctic stratosphere: Polar stratospheric clouds. Geophys. Res. Lett., 17, 385-388.

Cahoon, D. R., B. J. Stocks, J. S. Levine, W. R. Cofer, and J. M. Pierson, 1994: Satellite analysis of the severe 1987 forest fires in northern China and southeastern Siberia. J. Geophys. Res., 99, 18627-18638.

Cammas, J.-P., and Coauthors, 2009: Injection in the lower stratosphere of biomass fire emissions followed by long-range transport: A MOZAIC case study. Atmos. Chem. Phys., 9, 5829-5846. 
Carnuth, W., U. Kempfer, and T. Trickl, 2002: Highlights of the tropospheric lidar studies at IFU within the TOR project. Tellus, 54B, 163-185.

Chazette P., C. David, J. Lefrere, S. Godin, J. Pelon, and G. Mégie, 1995: Comparative study of the optical, geometrical, and dynamical properties of post-volcanic aerosols, following the eruptions of El Chichon and Mount Pinatubo. J. Geophys. Res., 100, 23 195-23 207.

Clancy, R. T., 1986: El Chichon and "mystery cloud" aerosols between 30 and $55 \mathrm{~km}$ : Global observations from the SME visible spectrometer. Geophys. Res. Lett., 13, 937-940.

Cunningham, P., and M. J. Reeder, 2009: Severe convective storms initiated by intense wildfires: Numerical simulations of pyro-convection and pyro-tornadogenesis. Geophys. Res. Lett., 36, L12812, doi:10.1029/2009GL039262.

Damoah, R., and Coauthors, 2006: A case study of pyro-convection using transport model and remote sensing data. Atmos. Chem. Phys., 6, 173-185.

Deshler, T., 2008: A review of global stratospheric aerosol: Measurements, importance, life cycle, and local stratospheric aerosol. Atmos. Res., 90, 223-232.

— , and Coauthors, 2006: Trends in the nonvolcanic component of stratospheric aerosol over the period 1971-2004. J. Geophys. Res., 111, D01201, doi:10.1029/2005JD006089.

Dessler, A. E., T. F. Hanisco, and S. Fueglistaler, 2007: Effects of convective ice lofting on $\mathrm{H}_{2} \mathrm{O}$ and $\mathrm{HDO}$ in the tropical tropopause layer. J. Geophys. Res., 112, D18309, doi:10.1029/2007JD008609.

Draxler, R., and G. Rolph, cited 2010: HYSPLIT (Hybrid Single-Particle Lagrangian Integrated Trajectory) model. NOAA Air Resources Laboratory. [Available online at http://ready.arl.noaa.gov/HYSPLIT.php.]

Ebert, C. H. V., 1963: The meteorological factor in the Hamburg fire storm. Weatherwise, 16, 70-75.

Eloranta, E. W., and D. K. Forrest, 1992: Volume imaging lidar observations of the convective structure surrounding the flight path of a flux-measuring aircraft. J. Geophys. Res., 97 (D17), 18 383-18 393.

Evans, W., and J. Kerr, 1983: Estimates of the amount of sulfur dioxide injected into the stratosphere by the explosive volcanic eruptions: El Chichon, mystery volcano, Mt. St. Helens. Geophys. Res. Lett., 10, 1049-1051.

Ffolliott, P., C. Stropki, and D. Neary, 2008: Historical wildfire impacts on ponderosa pine tree overstories: An Arizona case study. USDA Forest Service, Rocky Mountain Research Station Research Paper RMRSRP-75, 24 pp. [Available online at www.fs.fed.us/rm/ pubs/rmrs_rp075.pdf.]
Fromm, M. D., and R. Servranckx, 2003: Transport of forest fire smoke above the tropopause by supercell convection. Geophys. Res. Lett., 30, 1542, doi:10.1029/2002GL016820.

— , and Coauthors, 2000: Observations of boreal forest fire smoke in the stratosphere by POAM III, SAGE II, and lidar in 1998. Geophys. Res. Lett., 27, 1407-1410.

—, R. Bevilacqua, R. Servranckx, J. Rosen, J. Thayer, J. Herman, and D. Larko, 2005: Pyro-cumulonimbus injection of smoke to the stratosphere: Observations and impact of a super blowup in northwestern Canada on 3-4 August 1998. J. Geophys. Res., 110, D08205, doi:10.1029/2004JD005350.

_-, A. Tupper, D. Rosenfeld, R. Servranckx, and R. McRae, 2006: Violent pyro-convective storm devastates Australia's capital and pollutes the stratosphere. Geophys. Res. Lett., 33, L05815, doi:10.1029/2005GL025161.

- O. Torres, D. Diner, D. Lindsey, B. Vant Hull, R. Servranckx, E. P. Shettle, and Z. Li, 2008a: Stratospheric impact of the Chisholm pyrocumulonimbus eruption: 1. Earth-viewing satellite perspective. J. Geophys. Res., 113, D08202, doi:10.1029/2007JD009153.

- and Coauthors, 2008b: Stratospheric impact of the Chisholm pyrocumulonimbus eruption: 2. Vertical profile perspective. J. Geophys. Res., 113, D08203, doi:10.1029/2007JD009147.

Giglio, L., 2007: Characterization of the tropical diurnal fire cycle using VIRS and MODIS observations. Remote Sens. Environ., 108, 407-421.

Gobbi, G. P., F. Congeduti, and A. Adriani, 1992: Early stratospheric effects of the Pinatubo eruption. Geophys. Res. Lett., 19, 997-1000.

Gostintsev, Y., N. Kopylov, A. Ryzhov, and I. Khazanov, 1991: Numerical modeling of convective flows above large fires at various atmospheric conditions. Combust. Explos. Shock Waves, 27, 656-662.

Graham, R. T., Ed., 2003: Hayman fire case study. U.S. Department of Agriculture, Forest Service, Rocky Mountain Research Station, General Tech. Rep. RMRS-GTR-114, 396 pp. [Available online at www. fs.fed.us/rm/pubs/rmrs_gtr114.pdf.]

Haines, D. A., 1988: A lower atmospheric severity index for wildland fire. Natl. Wea. Dig., 13, 23-27.

Hansen, J., R. Ruedy, M. Sato, and R. Reynolds, 1996: Global surface air temperature in 1995: Return to pre-Pinatubo level. Geophys. Res. Lett., 23, 1665-1668.

Hirsch, K. G., 1991: A chronological overview of the 1989 fire season in Manitoba. For. Chron., 67, 358-365. 
ATMOSPHERIC

\section{Measurement}

\section{Instruments}
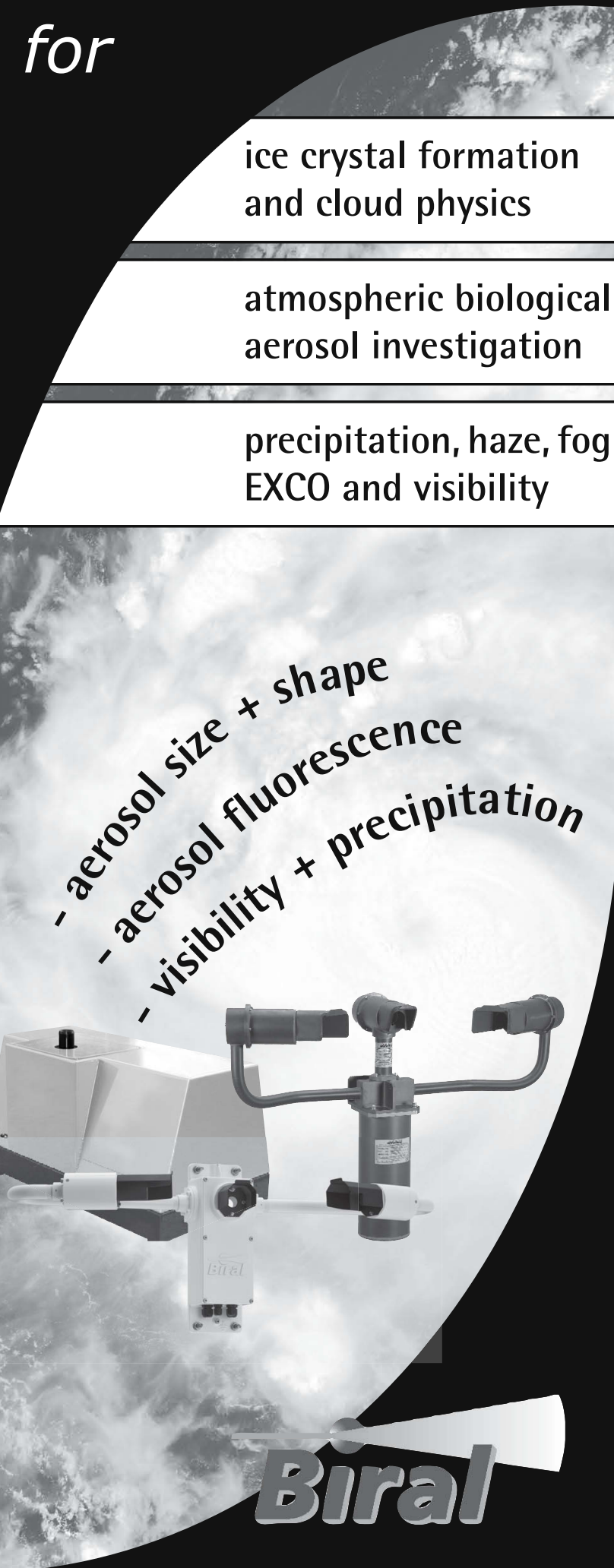

www.biral.com/bams

email: bams@biral.com
Hofmann, D. J., 1990: Increase in the stratospheric background sulfuric acid aerosol mass in the past 10 years. Science, 248, 996-1000.

—, J. Barnes, M. O’Neill, M. Trudeau, and R. Neely, 2009: Increase in background stratospheric aerosol observed with lidar at Mauna Loa Observatory and Boulder, Colorado. Geophys. Res. Lett., 36, L15808, doi:10.1029/2009GL039008.

Jäger, H., 1992: The Pinatubo eruption cloud observed by lidar at Garmisch Partenkirchen. Geophys. Res. Lett., 19, 191-194.

—, 2005: Long-term record of lidar observations of the stratospheric aerosol layer at GarmischPartenkirchen. J. Geophys. Res., 110, D08106, doi:10.1029/2004JD005506.

Jost, H., and Coauthors, 2004: In-situ observations of mid-latitude forest fire plumes deep in the stratosphere. Geophys. Res. Lett., 31, L11101, doi:10.1029/2003GL019253.

Junge, C. E., C. W. Chagnon, and J. E. Manson, 1961: Stratospheric aerosols. J. Atmos. Sci., 18, 81-108.

Kalnay, E., and Coauthors, 1996: The NCAR/NCEP 40-Year Reanalysis Project. Bull. Amer. Meteor. Soc., 77, 437-471.

Khaykin, S., and Coauthors, 2009: Hydration of the lower stratosphere by ice crystal geysers over land convective systems. Atmos. Chem. Phys., 9, 2275-2287.

Lindsey, D. T., and M. Fromm, 2008: Evidence of the cloud lifetime effect from wildfire-induced thunderstorms. Geophys. Res. Lett., 35, L22809, doi:10.1029/2008GL035680.

Livesey, N., M. Fromm, J. Waters, G. Manney, M. Santee, and W. Read, 2004: Enhancements in lower stratospheric $\mathrm{CH}_{3} \mathrm{CN}$ observed by Upper Atmosphere Research Satellite Microwave Limb Sounder following boreal forest fires. J. Geophys. Res., 109, D06308, doi:10.1029/2003JD004055.

Luderer, G., J. Trentmann, T. Winterrath, C. Textor, M. Herzog, H. F. Graf, and M. O. Andreae, 2006: Modeling of biomass smoke injection into the lower stratosphere by a large forest fire (Part II): Sensitivity studies. Atmos. Chem. Phys., 6, 5261-5277.

McCormick, M. P., and Coauthors, 1981: High-latitude stratospheric aerosols measured by the SAM II satellite system in 1978 and 1979. Science, 214, 328-331.

Nielsen, J. K., N. Larsen, F. Cairo, G. Di Donfrancesco, J. M. Rosen, G. Durry, G. Held, and J.-P. Pommereau, 2007: Solid particles in the tropical lowest stratosphere. Atmos. Chem. Phys., 7, 685-695.

Poulida, O., R. Dickerson, and A. Heymsfield, 1996: Stratosphere-troposphere exchange in a midlatitude mesoscale convective complex. 1. Observations. J. Geophys. Res., 101, 6823-6836. 
Pyne, S., and P. Omi, 1986: Wildland fires and nuclear winters: Selected reconstruction of historic large fires. Defense Documentation Center Rep. DNATR-85-396, 167 pp.

Quiring, S. M., and G. B. Goodrich, 2008: Nature and causes of the 2002 to 2004 drought in the southwestern United States compared with the historic 1953 to 1957 drought. Climate Res., 36, 41-52.

Randriambelo, T., J. L. Baray, S. Baldy, P. Bremaud, and S. Cautenet, 1999: A case study of extreme tropospheric ozone contamination in the tropics using in situ, satellite and meteorological data. Geophys. Res. Lett., 26, 1287-1290.

Rosenfeld, D., M. Fromm, J. Trentmann, G. Luderer, M. O. Andreae, and R. Servranckx, 2007: The Chisholm firestorm: Observed microstructure, precipitation and lightning activity of a pyro-cumulonimbus. Atmos. Chem. Phys., 7, 645-659.

Sassen, K., and J. Horel, 1990: Polarization lidar and synoptic analyses of an unusual volcanic aerosol cloud. J. Atmos. Sci., 47, 2881-2889.

Schoeberl, M., and L. Sparling, 1995: Trajectory modeling. Diagnostic Tools in Atmospheric Physics, Proceedings of the International School of Physics, Enrico Fermi, Course CXVI, G. Fiocco and G. Visconti, Eds., IOS Press, 289-305.

Sica, R. J., S. Sargoytchev, P. S. Argall, E. F. Borra, L. Girard, C. T. Sparrow, and S. and Flatt, 1995: Lidar measurements taken with a large-aperture liquid mirror. 1. Rayleigh-scatter system. Appl. Opt., 34, 6925-6936.

Smith, W. L., and C. M. Platt, 1978: Comparison of satellite-deduced cloud heights with indications from radiosonde and ground-based laser measurements. J. Appl. Meteor., 17, 1796-1802.

Smithsonian Institution, 1989: Santa Maria. Scientific Event Alert Network (SEAN) Bulletin, No. 1, Smithsonian Institution Archives, Washington, DC, 6-7. [Available online at www.volcano.si.edu/reports/.]

Stocks, B., and Coauthors, 1998: Climate change and forest fire potential in Russian and Canadian boreal forests. Climatic Change, 38, 1-13.

— , and Coauthors, 2002: Large forest fires in Canada, 1959-1997. J. Geophys. Res., 107, 8149, doi:10.1029/2001JD000484.

Thomason, L., 1992: Observations of a new SAGE II aerosol extinction mode following the eruption of Mt. Pinatubo. Geophys. Res. Lett., 19, 2179-2182.

— spheric aerosol properties. SPARC Rep. 4, WCRP124, WMO/TD- No. 1295.

— L. R. Poole, and T. Deshler, 1997: A global climatology of stratospheric aerosol surface area density deduced from stratospheric aerosol and gas experi- ment II measurements: 1984-1994. J. Geophys. Res., 102, 8967-8976.

— M. C. Pitts, and D. M. Winker, 2007: CALIPSO observations of stratospheric aerosols: A preliminary assessment. Atmos. Chem. Phys., 7, 5283-5290.

Thompson, A., and Coauthors, 1996: Where did tropospheric ozone over southern Africa and the tropical Atlantic come from in October 1992? Insights from TOMS, GTE TRACE A, and SAFARI 1992. J. Geophys. Res., 101, 24251-24278.

Toon, O. B., E. V. Browell, S. Kinne, and J. Jordan, 1990: An analysis of lidar observations of polar stratospheric clouds. Geophys. Res. Lett., 17, 393-396.

Torres, O., P. K. Bhartia, J. R. Herman, Z. Ahmad, and J. Gleason, 1998: Derivation of aerosol properties from satellite measurements of backscattered ultraviolet radiation: Theoretical basis. J. Geophys. Res., 103, 17 099-17 110.

Trentmann, J., and Coauthors, 2006: Modeling of biomass smoke injection into the lower stratosphere by a large forest fire (Part I): Reference simulation. Atmos. Chem. Phys., 6, 5247-5260.

Trepte, C. R., and M. H. Hitchman, 1992: Tropical stratospheric circulation diagnosed in satellite aerosol data. Nature, 355, 626-628.

Turco, R., O. Toon, T. Ackerman, J. Pollack, and C. Sagan, 1983: Nuclear winter: Global consequences of multiple nuclear explosions. Science, 222, 1283-1292.

U.S. Forest Service, 2004: California fire siege 2003: The story. U.S. Forest Service Government Doc. A 13.2:C 12/8, 98 pp. [Available online at www.fs.fed.us/r5/ fire/information/story/2003/index.php.]

Wang, P. K., 2007: The thermodynamic structure atop a penetrating convective thunderstorm. Atmos. Res., 83, 254-262.

Webb, R., C. J. Davis, and S. Lellyett, 2004: Meteorological aspects of the ACT bushfires of January 2003. Proc. Conf. Bushfire 2004: Earth, Wind and Fire-Fusing the Elements, Adelaide, Australia, South Australian Department of Environment and Heritage, CD-ROM, 25-28.

Westerling, A. L., H. G. Hidalgo, D. R. Cayan, and T. W. Swetnam, 2006: Warming and earlier spring increase western US forest wildfire activity. Science, 313, 940-943.

Westphal, D., and O. Toon, 1991: Simulations of microphysical, radiative, and dynamic processes in a continental-scale forest-fire smoke plume. J. Geophys. Res., 96, 22 379-22 400.

Yue, G. K., R. E. Veiga, and P. Wang, 1994: SAGE II observations of a previously unreported stratospheric volcanic aerosol cloud in the northern polar summer of 1990. Geophys. Res. Lett., 21, 429-432. 


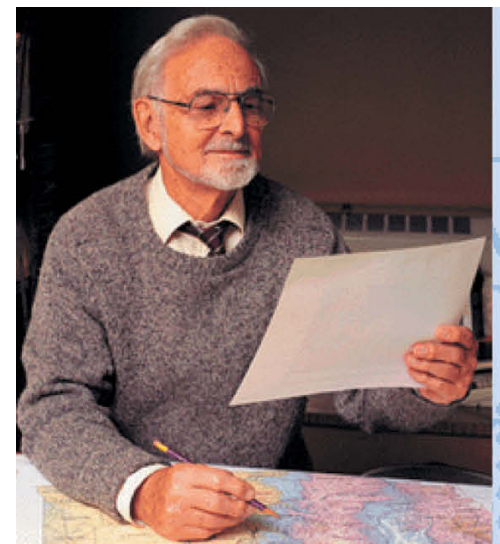

A Half Century of Progress in Meteorology:

A Tribute to Richard Reed

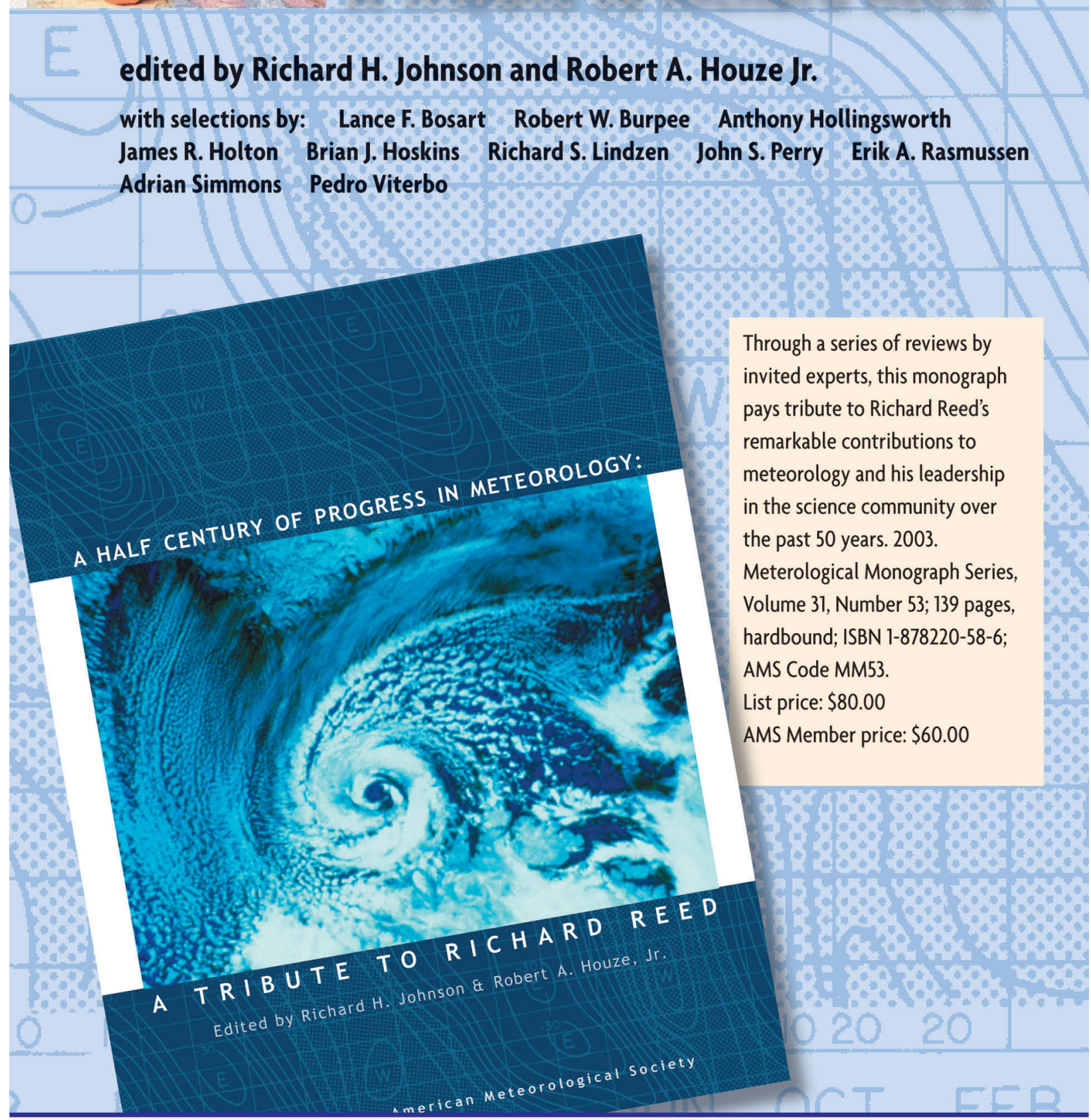

ORDER ONLINE: www.ametsoc.org/amsbookstore or see the order form at the back of this issue 